\title{
The Hippocampal Vulnerability to Herpes Simplex Virus Type I Infection: Relevance to Alzheimer's Disease and Memory Impairment
}

\author{
Shin Jie Yong ${ }^{1}$, Min Hooi Yong ${ }^{2,3}$, Seong Lin Teoh", Tomoko Soga ${ }^{5}$, Ishwar Parhar, \\ Jactty Chew ${ }^{1 *}$ and Wei Ling Lim ${ }^{1,3 *}$ \\ 1 Department of Biological Sciences, School of Medical and Life Sciences, Sunway University, Petaling Jaya, Malaysia, \\ ${ }^{2}$ Department of Psychology, School of Medical and Life Sciences, Sunway University, Petaling Jaya, Malaysia, ${ }^{3}$ Aging \\ Health and Well-being Research Centre, School of Medical and Life Sciences, Sunway University, Petaling Jaya, Malaysia, \\ ${ }^{4}$ Department of Anatomy, Universiti Kebangsaan Malaysia Medical Centre, Kuala Lumpur, Malaysia, ${ }^{5}$ Jeffrey Cheah School \\ of Medicine and Health Sciences, Brain Research Institute Monash Sunway, Monash University Malaysia, \\ Subang Jaya, Malaysia
}

OPEN ACCESS

Edited by:

Jorge Rubén Cabrera, Laboratory Corporation of America Holdings (LabCorp), United States

Reviewed by: Gabriela O. Bodea, University of Queensland, Australia Giovanna De Chiara, Institute of Traslational Pharmacology, Italian National Research Council, Italy

*Correspondence: Jactty Chew jacttyc@sunway.edu.my Wei Ling Lim weilingl@sunway.edu.my

Specialty section: This article was submitted to Cellular Neuropathology, a section of the journal Frontiers in Cellular Neuroscience

Received: 15 April 2021

Accepted: 20 July 2021

Published: 13 August 2021

Citation:

Yong SJ, Yong MH, Teoh SL, Soga T, Parhar I, Chew J and Lim WL (2021) The Hippocampal Vulnerability to Herpes Simplex Virus Type I Infection: Relevance to Alzheimer's Disease and Memory Impairment. Front. Cell. Neurosci. 15:695738. doi: 10.3389/fncel.2021.695738
Herpes simplex virus type 1 (HSV-1) as a possible infectious etiology in Alzheimer's disease (AD) has been proposed since the 1980s. The accumulating research thus far continues to support the association and a possible causal role of HSV-1 in the development of AD. HSV-1 has been shown to induce neuropathological and behavioral changes of $\mathrm{AD}$, such as amyloid-beta accumulation, tau hyperphosphorylation, as well as memory and learning impairments in experimental settings. However, a neuroanatomical standpoint of HSV-1 tropism in the brain has not been emphasized in detail. In this review, we propose that the hippocampal vulnerability to HSV-1 infection plays a part in the development of $A D$ and amnestic mild cognitive impairment (aMCl). Henceforth, this review draws on human studies to bridge HSV-1 to hippocampalrelated brain disorders, namely $\mathrm{AD}$ and $\mathrm{aMCl} / \mathrm{MCl}$. Next, experimental models and clinical observations supporting the neurotropism or predilection of HSV-1 to infect the hippocampus are examined. Following this, factors and mechanisms predisposing the hippocampus to HSV-1 infection are discussed. In brief, the hippocampus has high levels of viral cellular receptors, neural stem or progenitor cells (NSCs/NPCs), glucocorticoid receptors (GRs) and amyloid precursor protein (APP) that support HSV1 infectivity, as well as inadequate antiviral immunity against HSV-1. Currently, the established diseases HSV-1 causes are mucocutaneous lesions and encephalitis; however, this review revises that HSV-1 may also induce and/or contribute to hippocampal-related brain disorders, especially $\mathrm{AD}$ and $\mathrm{aMCl} / \mathrm{MCl}$.

Keywords: herpes simplex virus, hippocampus, neurotropism, Alzheimer's disease, memory impairment, infectious etiology

\section{INTRODUCTION}

Alzheimer's disease (AD) is the leading neurodegenerative disease, accounting for about $60-80 \%$ of dementia cases globally (Qiu et al., 2009; Alzheimer's Association., 2021). AD may progress from a long period of subtle memory decline called amnestic mild cognitive impairment (aMCI; the most common type of MCI) (Petersen et al., 2001). While the etiology of AD is multifaceted, the 
hypothesis for an infectious cause in $\mathrm{AD}$ has emerged since the 1980s. Ball (1982) and Gannicliffe et al. (1986) first suggested that periodic reactivation of herpes simplex virus type-1 (HSV1) from latency in neurons may facilitate the development of $\mathrm{AD}$. In the following decades, the possible involvement of herpes viruses, such as HSV-1, HSV-2, cytomegalovirus (CMV), human herpesvirus types 6,7 , and 8 (HHV-6, -7, and -8), varicellazoster virus (VZV) and Epstein-Barr virus (EBV), in AD and MCI have been investigated (Polk et al., 2002; Strandberg et al., 2003; Carbone et al., 2014; Barnes et al., 2015; Agostini et al., 2016b; Tsai et al., 2017; Tzeng et al., 2018). The collective evidence implicates HSV-1 as the most probable infectious agent contributing to $\mathrm{AD}$ and $\mathrm{MCI}$, according to reviews and meta-analyses (Steel and Eslick, 2015; Itzhaki et al., 2016; Warren-Gash et al., 2019; Sait et al., 2021).

HSV-1 is an enveloped, linear double-stranded DNA virus that infects more than $60 \%$ of the population worldwide (Looker et al., 2015; Harfouche et al., 2019; Khadr et al., 2019). Productive infection of HSV-1, either from primary infection or latent reactivation, causes mucocutaneous lesion of the lips, cornea or genitals (Darougar et al., 1985; Scott et al., 1997; Ribes et al., 2001). HSV-1 also causes herpes simplex encephalitis (HSE), the most common type of infection-induced encephalitis (Granerod et al., 2010; George et al., 2014). In pregnant mothers with genital herpes, HSV-1 can cause congenital herpes in the infant upon vaginal delivery, resulting in mucocutaneous lesions and central nervous system (CNS) infection (Whitley et al., 1991; Whitley et al., 2007).

At the neuronal level, HSV-1 infection has been shown to induce tau hyperphosphorylation, amyloid-beta 40 and 42 (A $\beta 40 / 42)$ accumulation, oxidative stress, neuroinflammation and apoptotic dysregulation, all of which are implicated in the pathophysiology of neurodegenerative diseases such as AD. At the genetic level, gene products of the HSV-1 life cycle have been shown to interact with AD susceptibility genes, such as presenilin 1 and 2 (PSEN1 and PSEN2), apolipoprotein E allele 4 (ApoE4) and clusterin genes, to promote both viral infectivity and risk of AD. These molecular mechanisms of HSV-1-induced neuropathology in AD have been reviewed in Harris and Harris (2018) and Duarte et al. (2019). Consequently, at the behavioral level, HSV-1 infection has been found to induce memory and learning impairments reminiscent of AD (Beers et al., 1995; Armien et al., 2010; De Chiara et al., 2019).

While molecular mechanisms underpinning contributions of HSV-1 to AD have been reviewed extensively (Duarte et al., 2019; Marcocci et al., 2020), a neuroanatomical standpoint has not been considered in detail. Deciphering the HSV-1 infection pathway and tropism in the brain would advance the understanding of the potential neurological health outcomes of HSV-1 infection. This review, thus, examines which brain region is most affected by HSV-1. Literature to date suggests that it may be the hippocampus, given its cardinal role in learning and memory. The hippocampus and its neuronal connections to the entorhinal cortex, amygdala, olfactory bulb and hypothalamus comprise the limbic system (Vilensky et al., 1982). In the mammalian hippocampus, life-long neurogenesis has been shown to occur in the subgranular zone of the dentate gyrus (DG), where neural stem or progenitor cells (NSCs/NPCs) are localized (Altman and Das, 1965; Eriksson et al., 1998). The hippocampus is susceptible to various stressors, including chronic stress, aging and microbial infections. As a result, hippocampal functions such as learning and memory would be compromised. Hence, hippocampal dysfunction has been implicated in disorders that involve memory impairment as a symptom, such as depression, schizophrenia, dementia, aMCI/MCI and AD, as reviewed in Small et al. (2011) and Anand and Dhikav (2012).

This review first discusses the possible role of HSV-1 in the development of $\mathrm{AD}$ and $\mathrm{aMCI} / \mathrm{MCI}$ in humans. Next, this review describes the mechanisms of HSV-1 infection in neurons and theoretical model of HSV-1 infection trajectory, focusing on its neurotropism or predilection to target the hippocampus based on cell culture, animal and human autopsy evidence. We suggest that the hippocampal vulnerability to HSV-1 infection may also present a pivotal factor in initiating or facilitating the development of aMCI/MCI and AD. Following this, factors and mechanisms affecting the hippocampal susceptibility to HSV-1 infection are discussed.

\section{BRIDGING HSV-1 TO AD AND MEMORY IMPAIRMENT}

HSE, either due to primary infection or viral reactivation, is known to cause long-term neurological sequelae despite immediate antiviral treatments (Riancho et al., 2013; Armangue et al., 2018). Damage to the temporal lobe and limbic system (especially the hippocampus), as well as impairments in memory and behavior (e.g., emotional instability and irritability), have been frequently observed among HSE survivors (Kapur et al., 1994; Caparros-Lefebvre et al., 1996; Dagsdottir et al., 2014; Harris et al., 2020). Degeneration of similar brain regions and consequent phenotypic abnormalities in HSE resemble that of $\mathrm{AD}$. This observation has led to the hypothesis that repeated and periodic $\mathrm{HSV}-1$ reactivation may contribute to AD development, especially in the aging population with declining immunocompetence (Ball, 1982; Esiri, 1982b; Gannicliffe et al., 1986). Therefore, this section will describe the relationship between HSV-1 and AD and memory impairment, which may also reflect prodromal $\mathrm{AD}$, in humans.

\section{Alzheimer's Disease}

HSV-1 DNA has been detected within A $\beta$ depositions in postmortem brain tissues of $\mathrm{AD}$ patients compared to non-AD controls (Mori et al., 2004). The same study also found HSV-1 antigens within cortical neurons, providing the first evidence of possible HSV-1 reactivation in the AD brain (Mori et al., 2004). A further study reported that most HSV-1 DNA was localized within $\mathrm{A} \beta$ plaques in the cortices of $\mathrm{AD}$ patients (Wozniak et al., $2009 b)$. Furthermore, transcriptome analyses of brain specimens from cohorts of $\mathrm{AD}$ patients have revealed higher abundance of HSV-1 latency-associated transcripts (LATs; transcribed from HSV-1 DNA) than older adults without AD (Readhead et al., 2018). These results indicate that HSV-1 can infect the brain and is associated with $\mathrm{AD}$ neuropathology. 
When compared to age-matched healthy controls, individuals with $\mathrm{AD}$ and aMCI exhibited increased levels of anti-HSV-1 IgG antibodies (Costa et al., 2017; Agostini et al., 2019; Pandey et al., 2019), which also correlated with increased cortical volumes (Mancuso et al., 2014a,b). Similarly, increased antibody levels and avidity index against HSV-1 were found to be elevated in aMCI patients that did not develop $\mathrm{AD}$, compared to those who did. In the same study, HSV-1-specific antibody titers also correlated positively with hippocampal and amygdala volumes (Agostini et al., 2016a). Other studies have also found that aMCI patients displayed higher anti-HSV-1 IgG antibody levels and avidity index compared to that of both healthy controls and AD patients (Kobayashi et al., 2013; Costa et al., 2020). Taken together, these findings imply that robust antibody immunity against HSV-1 may prevent the brain atrophy progression of aMCI into $\mathrm{AD}$, possibly via antibody neutralization of HSV-1 that protects the brain against HSV-1-induced neuropathology (Mancuso et al., 2014a; Agostini et al., 2016a; Costa et al., 2020).

When anti-HSV-1 immunity is inadequate to control HSV-1 infection, periodic HSV-1 reactivation and productive infection may occur. One nationwide retrospective cohort study in Taiwan reported that individuals diagnosed with recurrent HSV-1 infection had a 2.8-fold higher risk of developing AD than uninfected individuals. More importantly, antiherpetic medications reduced such risk by about $90 \%$ compared to placebo (Tzeng et al., 2018). In another nationwide retrospective cohort study involving participants with HSV-1 or VZV infections and uninfected matched controls in Sweden, antiherpetic treatment was associated with a $10 \%$ reduced risk of dementia. In untreated patients, the risk of dementia increased by $50 \%$ compared to uninfected controls (Lopatko Lindman et al., 2021). A four-national (i.e., Wales, Scotland, Denmark and Germany) retrospective cohort study found that persons with HSV infection who were not given anti-herpetic medication had 18\% higher risk of dementia compared to uninfected controls, although this effect was present in the Germany cohort only (Schnier et al., 2021). In a smaller retrospective cohort study comprising HSV-1-seropositive older adults, antiherpetic prescription was associated with $70 \%$ lower risk of $\mathrm{AD}$ development compared to no prescription (Hemmingsson et al., 2021). Two aging prospective cohort studies have also found that the risk of AD was about twofold greater in those with $\operatorname{IgM}$ seropositivity for HSV-1 (Letenneur et al., 2008; Lovheim et al., 2015a). Taken together, these studies suggest that HSV-1 productive infection or reactivation may promote $\mathrm{AD}$ development, which may also be preventable with antiherpetic agents.

Interestingly, a longitudinal study reported that $\operatorname{IgM}$ seropositivity for HSV-1 was associated with memory decline, especially amongst carriers of ApoE4 (Lövheim et al., 2019). Likewise, in another prospective cohort study, ApoE4 carriers had a threefold increased risk of both $\mathrm{AD}$ and $\mathrm{HSV}-1$ reactivation (i.e., as indicated by IgM seropositivity or elevated IgG levels) compared to ApoE4-negative individuals (Linard et al., 2020). Therefore, host genetic risk factors such as ApoE4 may modulate the interactions between HSV-1 and AD risk.

However, several studies found no significant differences in HSV-1 IgG seropositivity (Wozniak et al., 2005;
Letenneur et al., 2008; Lovheim et al., 2015b) and HSV-1 DNA in the brain (Jamieson et al., 1991; Hemling et al., 2003; Pisa et al., 2017) between individuals with and without AD. This could be attributed to genetic factors that predispose HSV-1-infected individuals to AD. For instance, the presence of HSV-1 DNA or IgG seropositivity with ApoE4 gene has been shown to pose a greater risk factor in $\mathrm{AD}$ development than either one by itself (Lin et al., 1995, 1996; Itzhaki et al., 1997; Steel and Eslick, 2015; Lopatko Lindman et al., 2019). Another reason may be that HSV-1 IgG seropositivity and DNA only indicate a history of viral exposure, as HSV-1 may remain latent and non-infective. Other meta-analyses have found that HSV-1-specific IgM seropositivity and high IgG levels (i.e., indicating productive infection or reactivation) were associated with dementia and MCI, but not HSV-1 IgG seropositivity and DNA (Warren-Gash et al., 2019; Ou et al., 2020; Wu et al., 2020).

\section{Memory Impairment}

As mounting evidence supports the link between HSV-1 infection and AD development, HSV-1 may also be associated with the prodromal stage of $\mathrm{AD}$, aMCI. Patients with aMCI may show early signs of $\mathrm{AD}$ neuropathological attributes, such as hippocampal shrinkage, neurofibrillary tangles (NFT; aggregates of hyperphosphorylated tau) and A $\beta 40 / 42$ accumulation, according to a systematic review (Stephan et al., 2012). Hippocampal neuroimaging has also been demonstrated to predict whether MCI patients would develop AD (Jack et al., 1999; Hu et al., 2016; Li et al., 2019). Thus, given that HSV-1 infection can induce hippocampal dysfunction, HSV-1 infection may also be associated with reduced memory function.

For instance, HSV-1 IgG seropositivity has been associated with an 18-fold increased odds of memory deficits in middleaged adults (Dickerson et al., 2008). Associations between HSV-1 IgG seropositivity and impaired cognition were also reported in other groups, e.g., healthy soldiers (Fruchter et al., 2015), young individuals (Tarter et al., 2014; Vanyukov et al., 2018) and older adults (Zhao et al., 2020; Murphy et al., 2021). Therefore, the clinical biomarker of HSV-1 exposure (i.e., IgG seropositivity) is likely to be linked to impaired memory and other cognitive measures, while biomarkers of HSV-1 reactivation or productive infection (i.e., high IgG levels or IgM seropositivity) is linked to AD (Letenneur et al., 2008; Lovheim et al., 2015a; WarrenGash et al., 2019). This indicates that HSV-1 reactivation or productive infection may promote more severe cognitive decline than mere HSV-1 exposure. In a population study comprising healthy adolescents, HSV-1 IgG seropositivity was associated with memory decline, whereas HSV-1 IgG levels correlated with both poor memory and executive functioning (Jonker et al., 2014).

Population studies have also reported that IgG levels specific for either HSV-1 or CMV independently predicted cognitive defect in the elderly (Strandberg et al., 2003), schizophrenics and their non-psychotic relatives (Shirts et al., 2008; Watson et al., 2013), and middle-aged adults (Tarter et al., 2014). However, some studies found that only CMV-specific (and not HSV-1-specific) IgG seropositivity or levels correlated with cognitive impairment in elderly populations (Aiello et al., 2006; 
TABLE 1 | Animal infection models assessing the neuronal invasion and spread of HSV-1.

\begin{tabular}{|c|c|c|c|c|}
\hline $\begin{array}{l}\text { Model of } \\
\text { infection }\end{array}$ & $\begin{array}{l}\text { Site of viral } \\
\text { dissemination }\end{array}$ & Site of latency & $\begin{array}{l}\text { Neurological and } \\
\text { behavioral findings }\end{array}$ & References \\
\hline \multicolumn{5}{|l|}{ Lip infection } \\
\hline $\begin{array}{l}\text { Infection by lip } \\
\text { abrasion into } \\
\text { C57BL/6 mice } \\
\text { (newborn; PND } \\
\text { 0-1) }\end{array}$ & • Hippocampus & $\bullet T G$ & $\begin{array}{l}\text { Accumulation of } \\
\text { A } 440 / 42 \text { peptides and } \\
\text { reduced neurogenesis } \\
\text { in the hippocampus. }\end{array}$ & Li Puma et al., 2019 \\
\hline $\begin{array}{l}\text { Infection by lip } \\
\text { abrasion into } \\
\text { BALB/c and } \\
\text { 3xTg-AD mice } \\
\text { (young; } \\
\text { 6-8 weeks) }\end{array}$ & & & $\begin{array}{l}\text { Upregulated oxidative } \\
\text { stress markers (HNE, } \\
\text { HNE-modified proteins, } \\
\text { protein carbonyls and } \\
\text { 3-nitrotyrosine) in } \\
\text { cortex. }\end{array}$ & Protto et al., 2020 \\
\hline
\end{tabular}

\begin{tabular}{|c|c|c|c|c|}
\hline Intranasal infe & & & & \\
\hline $\begin{array}{l}\text { Intranasal } \\
\text { inoculation into } \\
\text { BALB/C mice } \\
\text { (young; } \\
6 \text { weeks) }\end{array}$ & $\begin{array}{l}\text { - Hippocampus } \\
\text { - OB } \\
\text { - Trigeminal root entry } \\
\text { - Brainstem } \\
\text { - Amygdala } \\
\text { - Thalamus } \\
\text { - Hypothalamus } \\
\text { - Temporal lobe } \\
\text { - Cingulate cortex }\end{array}$ & N/A & $\begin{array}{l}\text { Neuronal degeneration } \\
\text { and acute inflammation } \\
\text { in infected areas, } \\
\text { especially the trigeminal } \\
\text { system. }\end{array}$ & Tomlinson and Esiri, 1983 \\
\hline $\begin{array}{l}\text { Intranasal } \\
\text { inoculation into } \\
\text { BALB/C mice } \\
\text { (young; } \\
\text { 6-8 weeks) }\end{array}$ & $\begin{array}{l}\text { - Hippocampus } \\
\text { - EC } \\
\text { - OB } \\
\text { - Trigeminal nerve } \\
\text { - Brainstem }\end{array}$ & N/A & N/A & Webb et al., 1989 \\
\hline $\begin{array}{l}\text { Intranasal } \\
\text { inoculation into } \\
\text { New Zealand } \\
\text { White rabbits } \\
\text { (adult) }\end{array}$ & $\begin{array}{l}- \text { EC } \\
-T G \\
\text { - OB } \\
\text { - Olfactory cortex }\end{array}$ & $\begin{array}{l}\text { - EC } \\
\text { - TG } \\
\text { - Olfactory cortex }\end{array}$ & $\begin{array}{l}\text { Acute inflammation in } \\
\text { olfactory structures, } \\
\text { including the EC. }\end{array}$ & Stroop et al., 1990 \\
\hline
\end{tabular}


TABLE 1 | Continued

\begin{tabular}{|c|c|c|c|c|}
\hline $\begin{array}{l}\text { Model of } \\
\text { infection }\end{array}$ & $\begin{array}{l}\text { Site of viral } \\
\text { dissemination }\end{array}$ & Site of latency & $\begin{array}{l}\text { Neurological and } \\
\text { behavioral findings }\end{array}$ & References \\
\hline $\begin{array}{l}\text { Intranasal } \\
\text { inoculation into } \\
\text { Lewis rats } \\
\text { (adult) }\end{array}$ & $\begin{array}{l}\text { - Hippocampus } \\
\text { - EC } \\
\text { - Amygdala } \\
\text { - TG } \\
\text { - OB }\end{array}$ & $\begin{array}{l}\text { - Hippocampus } \\
\text { - EC } \\
\text { - OB }\end{array}$ & $\begin{array}{l}\text { Inflammatory and } \\
\text { haemorrhagic lesions in } \\
\text { the TG, OB, amygdala, } \\
\text { EC, spinal trigeminal } \\
\text { nuclei and } \\
\text { hippocampus. }\end{array}$ & Beers et al., 1993 \\
\hline $\begin{array}{l}\text { Intranasal } \\
\text { inoculation into } \\
\text { Lewis rats, } \\
\text { followed by a } \\
\text { recovery period } \\
\text { from HSE } \\
\text { (adult) }\end{array}$ & $\begin{array}{l}\text { - Hippocampus } \\
\text { - EC }\end{array}$ & $\begin{array}{l}\text { - Hippocampus } \\
\text { - EC }\end{array}$ & $\begin{array}{l}\text { Impairments in spatial } \\
\text { memory and learning. } \\
\text { Brain tissues remain } \\
\text { histologically normal. }\end{array}$ & Beers et al., 1995 \\
\hline $\begin{array}{l}\text { Intranasal } \\
\text { inoculation into } \\
\text { SJL/NBOM } \\
\text { mice (adult) }\end{array}$ & $\begin{array}{l}\text { - TG } \\
\text { - Olfactory epithelium }\end{array}$ & $\mathrm{N} / \mathrm{A}$ & $\begin{array}{l}\text { Cytopathic effects } \\
\text { found predominantly in } \\
\text { the hippocampus, } \\
\text { temporal and } \\
\text { frontobasal lobes, } \\
\text { thalamus, pons and } \\
\text { mesencephalon. }\end{array}$ & $\begin{array}{l}\text { Meyding-Lamade et al., } \\
1998,1999\end{array}$ \\
\hline $\begin{array}{l}\text { Intranasal } \\
\text { inoculation into } \\
\text { Albino Swiss } \\
\text { CD-1 mice } \\
\text { (young; } \\
\text { 6-10 weeks) }\end{array}$ & $\begin{array}{l}\text { - Hippocampus } \\
\text { - EC } \\
\text { - OB } \\
\text { - Amygdala } \\
\text { - Frontal lobe } \\
\text { - Temporal lobe }\end{array}$ & $\mathrm{N} / \mathrm{A}$ & $\begin{array}{l}\text { HSV-1 replicated in the } \\
\text { brain without producing } \\
\text { neurological or } \\
\text { behavioral anomalies. }\end{array}$ & Boggian et al., 2000 \\
\hline $\begin{array}{l}\text { Intranasal } \\
\text { inoculation into } \\
\text { BALB/c mice to } \\
\text { induce } \\
\text { encephalitis } \\
\text { (young; } \\
\text { 8-10 weeks) }\end{array}$ & $\begin{array}{l}\text { - Hippocampus } \\
\text { - Trigeminal nerve } \\
\text { - OB } \\
\text { - Thalamus } \\
\text { - Hypothalamus } \\
\text { - Temporal cortex } \\
\text { - Piriform cortex }\end{array}$ & $\mathrm{N} / \mathrm{A}$ & $\begin{array}{l}\text { Glial cells necrosis and } \\
\text { myelin degeneration } \\
\text { within the hippocampus } \\
\text { and lateral tegmental } \\
\text { nucleus. Neuronal loss } \\
\text { in the hippocampus } \\
\text { (most profound), EC, } \\
\text { amygdala and temporal } \\
\text { cortex. Lymphocytic } \\
\text { infiltration in the } \\
\text { hippocampus and } \\
\text { temporal cortex. Mice } \\
\text { exhibited severe } \\
\text { learning deficits. }\end{array}$ & Armien et al., 2010 \\
\hline
\end{tabular}


TABLE 1 | Continued

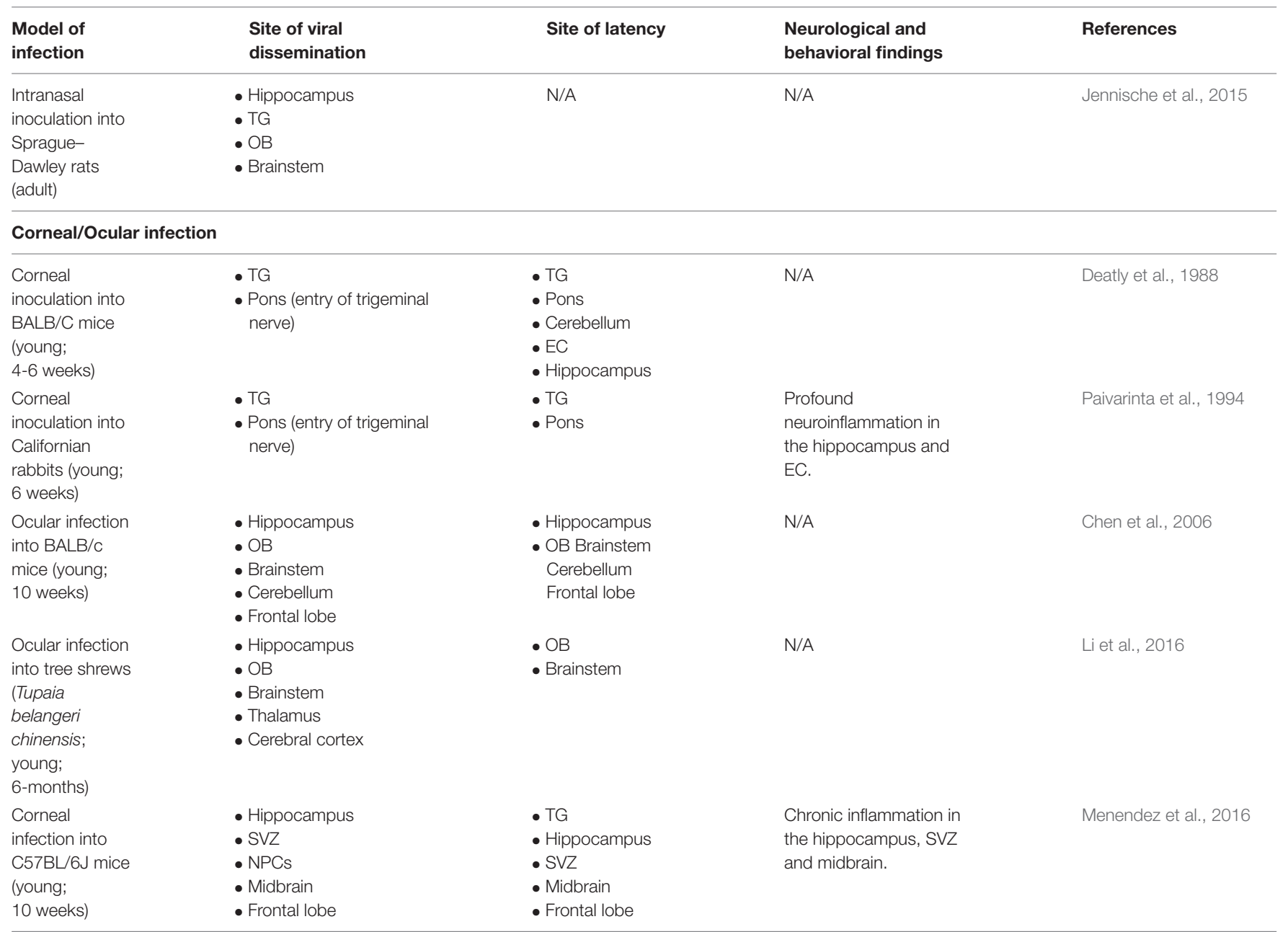

\section{Brain infection}

\begin{tabular}{|c|c|c|c|c|}
\hline $\begin{array}{l}\text { Intracerebral } \\
\text { inoculation into } \\
\text { BALB/C mice } \\
\text { (young; } \\
\text { 3-4 weeks) }\end{array}$ & $\begin{array}{l}\text { - Hippocampus } \\
\text { - Hypothalamus } \\
\text { - Cerebral cortex }\end{array}$ & N/A & N/A & Anderson and Field, 1983 \\
\hline $\begin{array}{l}\text { HSV-1 vector } \\
\text { propagation in } \\
\text { an ex vivo } \\
\text { system of } \\
\text { brains of } \\
\text { BALB/c mice } \\
\text { and SABRA } \\
\text { rats (newborn; } \\
\text { PND 1-2 and } \\
\text { young; } \\
4 \text { weeks) }\end{array}$ & $\begin{array}{l}\text { - Hippocampus } \\
\text { - NPCs } \\
\text { - Ependymal cells } \\
\text { - Ventricles } \\
\text { - Cortical areas }\end{array}$ & N/A & N/A & Braun et al., 2006 \\
\hline
\end{tabular}


TABLE 1 | Continued

\begin{tabular}{|c|c|c|c|c|}
\hline $\begin{array}{l}\text { Model of } \\
\text { infection }\end{array}$ & $\begin{array}{l}\text { Site of viral } \\
\text { dissemination }\end{array}$ & Site of latency & $\begin{array}{l}\text { Neurological and } \\
\text { behavioral findings }\end{array}$ & References \\
\hline $\begin{array}{l}\text { Intracranial } \\
\text { infection into } \\
\text { transgenic } \\
\text { 5xFAD mice } \\
\text { (young; } \\
\text { 3-months) }\end{array}$ & $\begin{array}{l}\text { - Hippocampus } \\
\text { - Cortex }\end{array}$ & $\mathrm{N} / \mathrm{A}$ & $\begin{array}{l}\text { Accumulation of } A \beta 42 \\
\text { peptides. }\end{array}$ & Ezzat et al., 2019 \\
\hline $\begin{array}{l}\text { Intracranial } \\
\text { infection into } \\
\text { C57BL/6 mice } \\
\text { (age and } \\
\text { weight N/A) }\end{array}$ & - Hippocampus & $\mathrm{N} / \mathrm{A}$ & $\begin{array}{l}\text { Neuronal loss, } \\
\text { upregulated } \\
\text { inflammatory markers } \\
\text { (TNF, IL1- } \beta, \text { IL-6 and } \\
\text { IFN } \alpha / \text { IFN } \beta \text { ) and } \\
\text { suppressed } \\
\text { anti-inflammatory } \\
\text { (IL-10, SOCS } 2 \text { and } \\
\text { SOCS3) signals in the } \\
\text { hippocampus. }\end{array}$ & Toscano et al., 2020 \\
\hline
\end{tabular}

\begin{tabular}{|c|c|c|c|c|}
\hline \multicolumn{5}{|c|}{ Peripheral infection } \\
\hline $\begin{array}{l}\text { Intravenous } \\
\text { and sciatic } \\
\text { nerve } \\
\text { inoculation into } \\
\text { BALB/C mice } \\
\text { (young; } \\
\text { 3-4 weeks) }\end{array}$ & $\begin{array}{l}\text { - Brainstem } \\
\text { - Hypothalamus }\end{array}$ & N/A & N/A & Anderson and Field, 1983 \\
\hline $\begin{array}{l}\text { Intraperitoneally } \\
\text { inoculation into } \\
\text { female } \\
\text { C57BL/6 mice } \\
\text { (young; } \\
14 \text { weeks) }\end{array}$ & $\begin{array}{l}\text { - Hippocampus } \\
\text { - Ventricles } \\
\text { - Midbrain } \\
\text { - Cerebellum } \\
\text { - Cortex }\end{array}$ & $\begin{array}{l}\text { - TG } \\
\text { • Hippocampus }\end{array}$ & $\mathrm{N} / \mathrm{A}$ & Burgos et al., 2006 \\
\hline
\end{tabular}

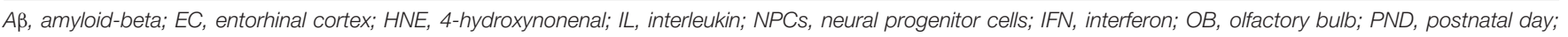
SOCS, suppressor of cytokine signaling; SVZ; subventricular zone; TG, trigeminal ganglion; TNF, tumor necrosis factor.

Barnes et al., 2015; Nimgaonkar et al., 2016) and bipolar disorder patients (Tanaka et al., 2017). On the contrary, other studies showed that only HSV-1-specific IgG (and not CMV-specific) seropositivity or levels were associated with cognitive impairment in healthy adolescents (Jonker et al., 2014) and individuals with or without neuropsychiatric disorders (Dickerson et al., 2003; Yolken et al., 2011; Hamdani et al., 2017).

A putative explanation for these inconsistencies could be that both CMV and HSV-1 contribute to memory dysfunction. It was suggested that $\mathrm{CMV}$, which is known to induce immune dysregulation, may exacerbate HSV-1-induced neurodegeneration, leading to AD (Stowe et al., 2012; Lovheim et al., 2018). This is based upon the finding that HSV-1specific IgG levels increased with age only in CMV seropositive individuals (Stowe et al., 2012). CMV IgG seropositivity alone also did not elevate the risk of AD, but both CMV and HSV-1 seropositivity did (Lovheim et al., 2018), suggesting that CMV and HSV-1 interact to influence the risk of developing AD. For AD with severe memory impairment, HSV-1 likely plays a more predominant role in memory impairment than other herpesviruses, as suggested by meta-analyses (Steel and Eslick, 2015; Warren-Gash et al., 2019) and reviews (Itzhaki, 2014; Itzhaki and Klapper, 2014).
One key limitation of these studies is that HSV-1 seropositivity indicates the history of prior HSV-1 exposure. Seropositivity alone does not inform the status of HSV-1 infection; that is, active or latent infection, or viral replication in the central or peripheral nervous systems or peripheral epithelial cells (Dickerson et al., 2008; Murphy et al., 2021). Therefore, the possible link of causality or pathophysiological pathways between HSV-1 seropositivity and memory impairment remains unclear (Vanyukov et al., 2018). Besides, the majority of the global adult population (i.e., > 60\%) is seropositive for HSV-1 (Looker et al., 2015; Harfouche et al., 2019; Khadr et al., 2019), whereas only relatively few develop memory impairment (i.e., 10-20\% of adults over 50 years) (Overton et al., 2019; Pais et al., 2020; Lu et al., 2021). This suggests that HSV-1 seropositivity may only play a subtle role in the development of memory impairment in certain cases.

\section{HSV-1 IN THE NERVOUS SYSTEM}

HSV-1 has four notable structures: the glycoproteins-embedded membrane, tegument layer, capsid and double-stranded DNA genome (Grunewald et al., 2003). Although HSV-1 is considered 


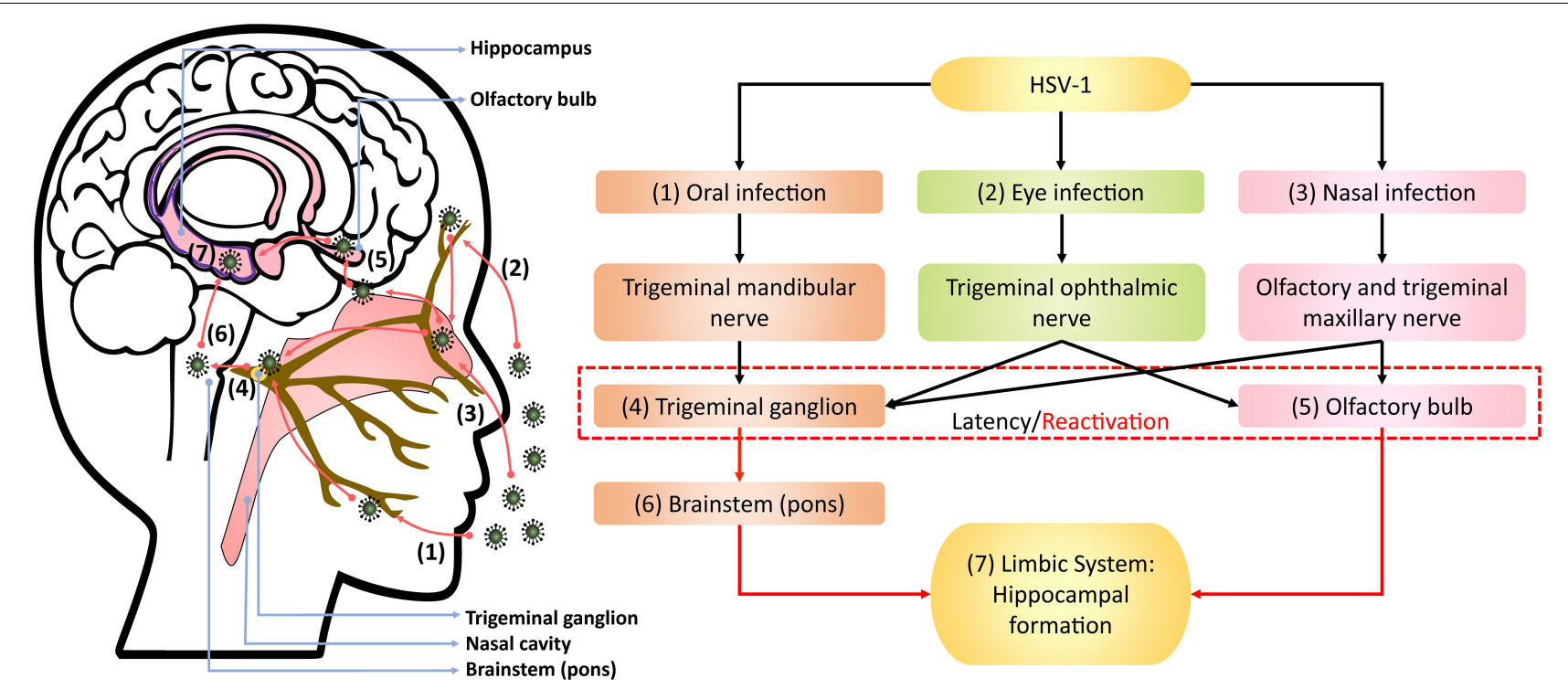

FIGURE 1 | Theoretical model of HSV-1 infection trajectory within the nervous system. Following viral replication in the (1) oral, (2) corneal, or (3) olfactory epithelial cells, HSV-1 can exploit the neuronal retrograde machinery to reach the (4) trigeminal ganglion and (5) olfactory bulb, which are also sites for HSV-1 latency and stress-induced reactivation. Reactivated HSV-1 relies on anterograde transport to infiltrate the brain. Therein, HSV-1 travels from the trigeminal ganglion to the (6) pons, a part of brainstem innervated by the trigeminal nerve, and then to the (7) limbic system that inhabits the hippocampal-entorhinal circuitry. Alternatively, HSV-1 may directly infect the hippocampal-entorhinal circuity via the olfactory bulb, which is part of the limbic system.

a human pathogen, it can infect other animals in experimental settings, as reviewed in Karasneh and Shukla (2011). The primary target cells of HSV-1 are epithelial and neuronal cells, where HSV-1 can alternate between lytic and latent life cycle phases, as reviewed in Kukhanova et al. (2014). This section will detail the mechanisms of HSV-1-neuronal interactions, followed by the theoretical model of HSV-1 infection trajectory in the nervous system.

\section{HSV-1 Infection and Latency}

First, HSV-1 attachment to cells depends on the binding of envelop glycoprotein B (gB) to surface heparan sulfate proteoglycans (HSPGs), with an optional gC to augment the interaction (WuDunn and Spear, 1989; Herold et al., 1991, 1994). Alternatively, gB can bind to myelin-associated glycoprotein (MAG) (Suenaga et al., 2009) and non-muscle myosin heavy chain IIA and IIB (NHMC-IIA and -IIB) to initiate viral entry (Arii et al., 2010, 2015). The subsequent binding of gD to 3O-sulfated heparan sulfate, herpesvirus entry mediator (HVEM) and/or nectin-1 (Montgomery et al., 1996; Whitbeck et al., 1997; Geraghty et al., 1998; Shukla et al., 1999) catalyzes viral fusion and entry via activation of gH/gL (Atanasiu et al., 2010).

Following HSV-1 entry, the DNA-containing nucleocapsid and tegument proteins are released into the cell cytoplasm. One of the tegument proteins may proceed to turn off protein translation in the cell (Kwong and Frenkel, 1987). The nucleocapsid moves and docks on the nuclear pore, which then disassembles to release the DNA into the cell nucleus (Sodeik et al., 1997; Dohner et al., 2002). This initiates a cascade of HSV-1 gene expression, in the order of $\alpha$-genes, $\beta$ genes and $\gamma$-genes, where viral structural proteins and DNA are synthesized and re-assembled (Honess and Roizman, 1974). The assembled viral particles may bud into the inner nuclear membrane and undergo primary envelopment for nuclear egress. HSV-1 particles may subsequently undergo de-envelopment at the outer nuclear membrane to allow for further viral assembly in the cytoplasm, and complete the secondary envelopment at Golgi vesicles before the mature virions egress out of the host cell (Hutchinson and Johnson, 1995; Granzow et al., 2001), as reviewed in Mettenleiter (2002).

After this lytic phase in peripheral epithelial cells, HSV-1 can proceed to the latent phase in neurons, typically in the trigeminal ganglion (Takasu et al., 1992; Theil et al., 2001; Hufner et al., 2009). The latent phase of HSV-1 starts similarly to the lytic phase, until HSV-1 reaches the nucleopore by retrograde axonal transport (Antinone and Smith, 2010). In the latent phase, HSV-1 lytic gene expression in the nucleus is silenced, and no infectious viral progeny is produced. Instead, HSV-1 DNA undergoes histone modifications with nucleosomes of the chromatin in cell nucleus (Deshmane and Fraser, 1989; Kubat et al., 2004; Wang et al., 2005). During latency, HSV-1 gene expression is limited to LATs and a few microRNAs, which may inhibit (i) lytic gene transcription to maintain latency and (ii) apoptosis to promote survival of infected neurons (Perng et al., 2000; Wang et al., 2005; Umbach et al., 2008).

HSV-1 can transition from latent to lytic phase under conditions of cellular stress, such as chemotherapy, hyperthermia, ultraviolet radiation, fever, immunosuppression and psychological stress, as reviewed in Suzich and Cliffe (2018) and Yan et al. (2020). During HSV-1 reactivation, the HSV-1 DNA-associated chromatin relaxes and transcription of the viral regulatory VP16 protein begins, which consequently activates a 
cascade of viral lytic gene expression that lead to the production of infectious viral progeny (Thompson et al., 2009; Kim et al., 2012; Sawtell and Thompson, 2016). Newly manufactured HSV-1 then travels by anterograde transport from the cell body to axon termini to infect neighboring epithelial cells or neurons (Snyder et al., 2008; Miranda-Saksena et al., 2009). HSV-1 reactivation can lead to the appearance of disease (e.g., cold sores and HSE), asymptomatic viral replication or spread into the CNS, as reviewed in Bearer (2012) and Marcocci et al. (2020).

Neurons with actively replicating HSV-1 via reactivation or primary infection begins to undergo various mechanisms that lead to pathological changes, as reviewed in Harris and Harris (2018) and Duarte et al. (2019). Neuronal culture studies have demonstrated that HSV-1 induced tau hyperphosphorylation by upregulating several enzymes such as caspase-3, protein kinase A and glycogen synthase kinase $3 \beta$ (Wozniak et al., 2009a; Lerchundi et al., 2011; Alvarez et al., 2012). HSV-1-infected neurons have also been shown to exhibit impaired autophagy and amyloid precursor protein (APP) processing, resulting in increased $A \beta 40 / 42$ accumulation (De Chiara et al., 2010; Santana et al., 2012; Piacentini et al., 2015). These HSV-1-induced ADrelated neuropathology can be inhibited with antiviral treatment targeting HSV-1 in vitro (Wozniak et al., 2011, 2013, 2005). These studies indicate that HSV-1 spread into the brain may facilitate the development of AD-related neuropathology. Animal models further provided support wherein HSV-1 infection or reactivation have been shown to induce $\mathrm{AD}$ neuropathology in the brain, which was also associated with learning and memory impairments (Martin et al., 2014; De Chiara et al., 2019).

\section{HSV-1 Infection Trajectory: Emphasis on Hippocampal Tropism}

In the brain, HSV-1 invasion has been shown to target the olfactory system and hippocampus, followed by the higher cortical areas in animal studies (Table 1). According to Braak's staging scheme in human AD samples, the hippocampusentorhinal circuitry within the temporal lobe deteriorates the earliest, followed by higher cortical areas (Braak and Braak, 1991). Increasing evidence has also suggested that dysfunction of the olfactory system may indicate prodromal AD in humans, as Murphy (2019) reviewed. With this anatomical resemblance, Fewster et al. (1991) and Ball et al. (2013) have previously suggested that HSV-1 might induce the neuron-to-neuron tauopathy and $\mathrm{A} \beta$ spread in $\mathrm{AD}$ as $\mathrm{HSV}-1$ propagates along its infection pathways.

Upon oral infection in animal models, HSV-1 can infect the mandibular trigeminal nerve to establish latency at the trigeminal ganglion (Barnett et al., 1994; Lewandowski et al., 2002; De Chiara et al., 2019). Alternatively, the nasal cavity can be an infection site wherein HSV-1 can travel along the olfactory and trigeminal maxillary nerves and become latent in the olfactory bulb and trigeminal ganglion of animals (Stroop et al., 1990; Beers et al., 1993; Jennische et al., 2015). Autopsy studies have also detected HSV-1 DNA, including LATs, in the trigeminal ganglion, trigeminal nerves and olfactory bulb of deceased humans (Liedtke et al., 1993; Theil et al., 2001;
Hufner et al., 2009). In animal studies, HSV-1 could also infect the eye, propagating along the corneal subbasal nerve plexus innervated by trigeminal ophthalmic nerve, to initiate latency in the olfactory bulb and trigeminal ganglion (He et al., 2017; Menendez and Carr, 2017; Figure 1). Although congenital herpes is usually contracted upon vaginal delivery, in utero infection can occur in 5\% of human infant cases (Hutto et al., 1987; Marquez et al., 2011). In such instances, using the murine model, genital HSV-1 likely enters the bloodstream and crosses the placenta into the fetal nervous system following the trigeminal infection route (Burgos et al., 2006).

Following reactivation from the trigeminal ganglion, HSV-1 may infiltrate the pons innervated by trigeminal nerves and then travel along the brainstem to the limbic system, as demonstrated in animal models (Tomlinson and Esiri, 1983; Webb et al., 1989; Barnett et al., 1994; Paivarinta et al., 1994). The olfactory bulb constitutes part of the limbic system and has direct projections to the hippocampus. Thus, reactivation from the olfactory bulb may provide HSV-1 and other neurotropic viruses direct access to the hippocampus, as proposed by Mori et al. (2005) and Duarte et al. (2019).

The theoretical model depicting neuronal pathways of HSV1 infection in the brain (Figure 1) is also consistent with autopsy examinations of HSV-1 antigen distribution amongst HSE patients. Specifically, HSV-1 antigens were localized mostly in the hippocampus with the highest number of cases and viral abundance found, as well as in the temporal lobe, olfactory bulb and amygdala (Dinn, 1979; Twomey et al., 1979; Esiri, 1982a,b). Notably, postmortem analysis of AD victims detected HSV-1 DNA more frequently in the hippocampus and temporal cortex compared to other brain areas (Jamieson et al., 1991, 1992). Damasio and Van Hoesen (1985) also hypothesized that HSV-1 travels to the limbic system via the trigeminal nerve, wherein HSV-1 may exhibit higher affinity for the hippocampus, and subsequently spread to cortices during HSE.

Most animal models investigating HSV-1 neurotropism following reactivation, primary infection, or both have supported the predilection of HSV-1 to infect the hippocampus (Table 1). Some studies induced stress in animal models to reactivate HSV-1 and showed that the consequent viral replication was particularly prominent in the hippocampus (Burgos et al., 2006; De Chiara et al., 2019). Further supporting evidence can be derived from animal findings that demonstrated impairment in hippocampusdependent memory and learning tasks following HSV-1 infection (McLean et al., 1993; Beers et al., 1995; Armien et al., 2010; De Chiara et al., 2019).

AD-associated neuropathology induced by HSV-1 can be observed in the hippocampus. For instance, multiple reactivations of HSV-1 caused memory deficits that were correlated with increased $A \beta$ accumulation, tau phosphorylation and neuroinflammation in the neocortex and hippocampal DG of mice (De Chiara et al., 2019). It was demonstrated that HSV-1 could form a protein corona layer that served as catalytic surfaces for $A \beta$ accumulation in the hippocampus and cortex of mice (Ezzat et al., 2019). Neurodegeneration and lymphocytic infiltration were also observed in the hippocampus, 
entorhinal cortex, amygdala and temporal cortex in HSV1-infected mice (Ando et al., 2008; Armien et al., 2010; Toscano et al., 2020). Moreover, HSV-1 has been shown to inhibit the proliferation and differentiation of hippocampal NSCs (Li Puma et al., 2019). In mature hippocampal neurons, acute HSV-1 infection has been shown to increase A $\beta 42$ accumulation and hyperphosphorylated tau compared to uninfected neurons (Powell-Doherty et al., 2020). Taken together, findings from neuronal culture, animal models and human autopsy studies implicate the hippocampus as the nexus between HSV-1 and memory-related disorders, such as $\mathrm{AD}$ and $\mathrm{aMCI} / \mathrm{MCI}$.

\section{SUSCEPTIBILITY FACTORS TOWARD HSV-1 INFECTION IN THE HIPPOCAMPUS}

Several biological factors potentially place the hippocampus at risk for HSV-1 infection compared to other brain regions, providing a mechanistic basis for the hippocampal tropism of HSV-1 (Table 2). For one, receptors for HSV-1 cellular entry are highly expressed in the hippocampus. The hippocampus is a site of active neurogenesis throughout adulthood, which may also favor HSV-1 infection. The impaired antiviral immunity in the hippocampus, especially during aging, may further render the hippocampus vulnerable to HSV-1 infection. HSV-1 may also capitalize on the high levels of hippocampal glucocorticoid receptors (GRs) to promote its virulence. Additionally, the high APP levels in the hippocampus may facilitate HSV-1 neuronal propagation. Details of these hippocampal susceptibility factors are further discussed below.

\section{High Expression of Cellular Receptors for HSV-1}

HSV-1 entry and infection in cells rely on the presence of viral envelop $\mathrm{gB}, \mathrm{gD}$ and $\mathrm{gH} / \mathrm{gL}$ and cell surface receptors for $\mathrm{gB}$ and gD. According to the Allen Brain Atlas transcriptome database of the adult human brain, the expression of receptors for the envelop glycoproteins of HSV-1, specifically gB (i.e., NHMCIIA and MAG receptors) and gD (i.e., HVEM and nectin-1 receptors), were found to be highest in the hippocampus by $2-$ 3 -fold compared to other brain regions (Lathe and Haas, 2017). The same study also found similar HSV-1 receptors being highly expressed in the murine hippocampus (Lathe and Haas, 2017). Immunohistochemical analyses have also revealed that nectin1 expression was particularly high in the hippocampus of mice and humans (Horvath et al., 2006; Prandovszky et al., 2008). Similarly, nectin-1 RNA was detected in large quantities in the murine hippocampus compared to other brain regions (Haarr et al., 2001). Aside from nectin-1, the distribution of other HSV-1 receptors in the brain has not been widely studied.

Furthermore, it was shown that the cerebellum lacks gD receptors (Lathe and Haas, 2017), which may explain the finding that HSV-1 inoculation into the cerebellum did not induce lethal
TABLE 2 | Susceptibility factors of the hippocampus toward HSV-1 infection.

\begin{tabular}{|c|c|c|}
\hline Susceptibility factor & Component & Function \\
\hline $\begin{array}{l}\text { High expression of viral } \\
\text { receptors }\end{array}$ & $\begin{array}{l}\uparrow \text { NMMHC-IIA } \\
\text { (MYH9) } \\
\uparrow M A G \\
\uparrow \text { HVEM } \\
\text { (TNFRSF14) } \\
\uparrow \text { Nectin-1 } \\
\text { (PVRL1 or } \\
\text { HveC) }\end{array}$ & $\begin{array}{l}\text { Binds to gB for HSV-1 } \\
\text { attachment Binds to gB for } \\
\text { HSV-1 fusion and entry }\end{array}$ \\
\hline $\begin{array}{l}\text { Abundance of NPCs/NSCs: } \\
\text { A neurogenic niche }\end{array}$ & $\uparrow \mathrm{HSPG}$ & $\begin{array}{l}\text { Binds to gB for HSV-1 } \\
\text { attachment }\end{array}$ \\
\hline $\begin{array}{l}\text { Inadequate antiviral } \\
\text { immunity }\end{array}$ & $\begin{array}{l}\downarrow \text { IL-6 } \\
\downarrow \text { Microglial } \\
\text { type I interferon }\end{array}$ & $\begin{array}{l}\text { Lowered resistance against } \\
\text { HSV-1 infection }\end{array}$ \\
\hline High expression of GR & $\uparrow \mathrm{GR}$ & $\begin{array}{l}\text { Interact with HSV-1 promoters } \\
\text { to enhance infectivity }\end{array}$ \\
\hline High expression of APP & $\uparrow \mathrm{APP}$ & Promote HSV-1 spread \\
\hline
\end{tabular}

Alternative names are bracketed; refer to the main text for relevant references. APP, amyloid precursor protein; GR, glucocorticoid receptor; HSPG, heparan sulfate proteoglycan; HveC; herpesvirus entry mediator C; HVEM, herpesvirus entry mediator; IL-6, Interleukin-6; MAG, myelin-associated glycoprotein; MHY9, myosin heavy chain 9; NMMHC-IIA, non-muscle myosin heavy chain-IIA; PVRL1, poliovirus receptor-like 1; TNFRSF14, tumor necrosis factor receptor superfamily, member 14.

disease in mice (McFarland and Hotchin, 1987). This was in contrast to the pervasive viral spread and death when HSV-1 was inoculated into the murine hippocampus instead (McFarland and Hotchin, 1987). Another study also showed that HSV-1 binds more strongly to the murine hippocampus than the brainstem and cerebellum (McFarland et al., 1982). Based on animal models investigating HSV-1 spread in the brain, HSV-1 infects the hippocampus in most studies, and rarely targets the cerebellum (Table 1). Therefore, the HSV-1 tropism for the hippocampus may be attributed to the high expression of viral $\mathrm{gB}$ and $\mathrm{gD}$ receptors in the hippocampus.

\section{Abundance of NSCs/NPCs: A Neurogenic Niche}

As demonstrated ex vivo, the hippocampus and periventricular areas of neonate mice were particularly susceptible to HSV1 infection (Braun et al., 2006). The viral dissemination into these brain regions where neuronal differentiation is active suggests that dividing cells are more vulnerable to HSV-1 infection (Braun et al., 2006). Using organotypic hippocampal cultures, it was shown that the hippocampal DG (i.e., the chief neurogenic niche) was most vulnerable to HSV-1 infection compared to hippocampal glia and other neuronal types (Ando et al., 2008). Another study also showed that HSV-1 preferentially infects undifferentiated NSCs rather than mature hippocampal neurons, resulting in impaired hippocampal neurogenesis ( $\mathrm{Li}$ Puma et al., 2019). More recent studies have shown that HSV1 readily infects NSCs/NPCs and induces A $\beta 42$ accumulation, neuroinflammation and neuronal impairments, which can be prevented with valacyclovir antiherpetic treatment (Abrahamson et al., 2020; Cairns et al., 2020; Zheng et al., 2020). 


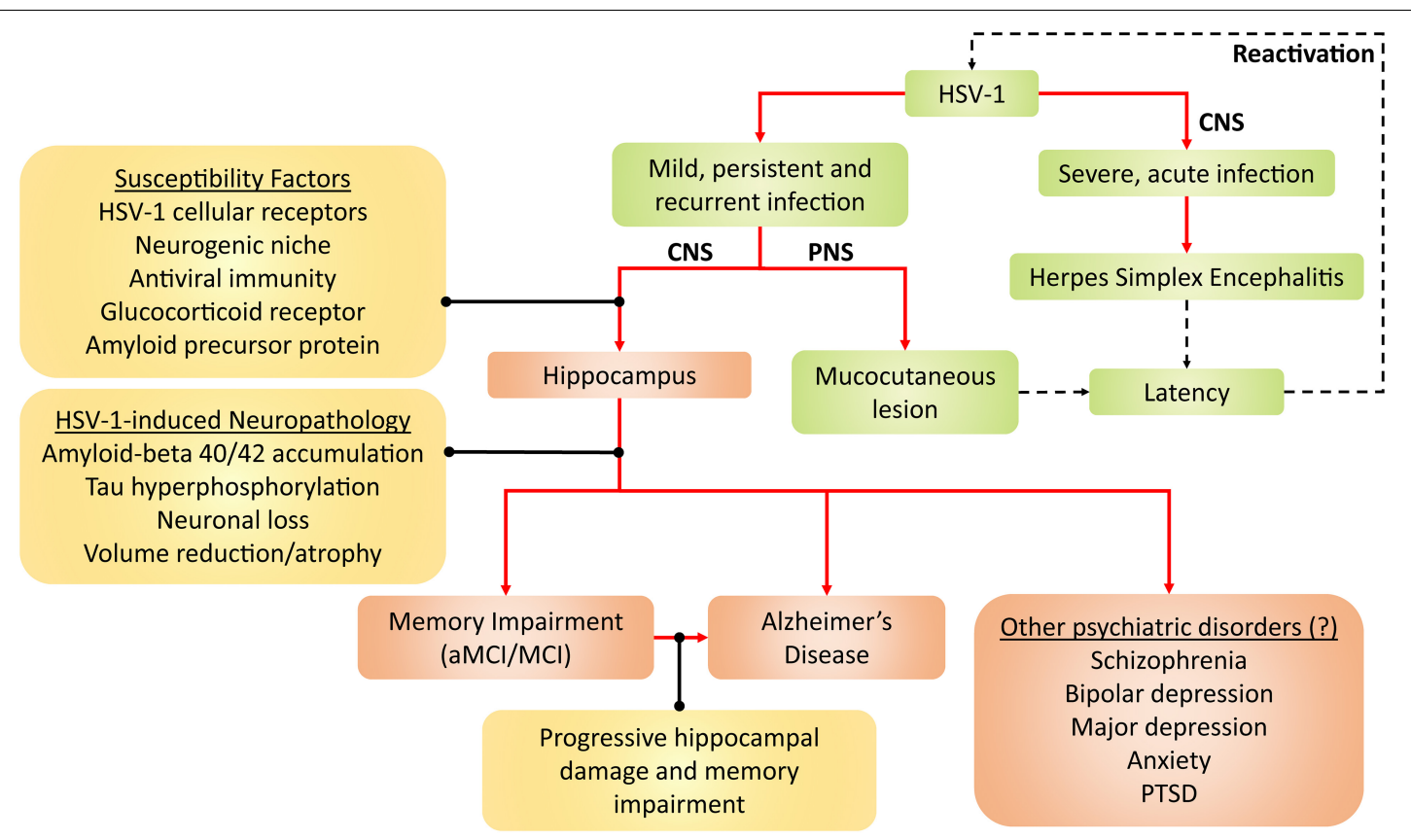

FIGURE 2 | Framework for HSV-1 pathogenicity. Green denotes established disease pathways wherein mild HSV-1 infection causes mucocutaneous lesions of the lips (cold sores), genitals (genital herpes), and cornea (keratitis). Severe HSV-1 infection causes herpes simplex encephalitis (HSE). Following productive infection (dashed arrows), HSV-1 establishes latency in the trigeminal ganglion and olfactory bulb, and periodically reactivates. Red-brown denotes current and emerging putative pathogenicity pathways, wherein HSV-1 preferentially infects the hippocampus due to several susceptibility factors. HSV-1 consequently induces neuropathological effects and, thus, compromises hippocampal functions. As a result, memory becomes impaired, which may lead to aMCI/MCl and AD. Alternatively, the progressive HSV-1-induced hippocampal damage may facilitate the progression from aMCl/MCl to AD. Given that hippocampal dysfunction may be present in other neuropsychiatric disorders such as schizophrenia, PTSD, depressive and anxiety disorders, HSV-1 may hypothetically contribute to such disorders as well. A $\beta$, amyloid-beta; AD, Alzheimer's disease; aMCl, amnestic mild cognitive impairment; CNS, central nervous system; HSV-1, herpes simplex virus type 1; $\mathrm{MCl}$, mild cognitive impairment; PNS, peripheral nervous system; PTSD, post-traumatic stress disorder.

The vulnerability of dividing, undifferentiated NSCs in the hippocampal DG to HSV-1 infection could be attributed to the high expression of surface HSPGs. HSPGs comprise a family of two glycoproteins, syndecans and glypicans, which are highly expressed throughout mammalian neurogenesis (Hagihara et al., 2000; Wang et al., 2012; Oikari et al., 2016; Yu et al., 2017). HSPGs regulate basic fibroblast growth factor (bFGF; NSCs mitogen) to initiate neurogenesis (Rapraeger et al., 1991; Yayon et al., 1991; Vicario-Abejon et al., 1995). However, HSPGs also mediate HSV-1 attachment to mammalian cell surfaces (WuDunn and Spear, 1989; Herold et al., 1991, 1994). HSV-1 infection in mice has also been shown to downregulate FGF-2 expression and NSCs proliferation (Rotschafer et al., 2013). Similarly, reactivating HSV-1 in mice resulted in A $340 / 42$ accumulation in the hippocampal NSCs, disrupting neurogenesis (Li Puma et al., 2019). Therefore, HSPGs play dual roles in promoting NSCs proliferation and HSV-1 cell attachment.

In addition, surface HSPGs have been implicated in the pathogenesis of AD (Zhang et al., 2014). HSPGs expression has been detected in $A \beta$ plaques and NFTs in cortical areas and more frequently in the hippocampus of AD patients (Snow et al., 1992; Bignami et al., 1994; Verbeek et al., 1999). This indicates that existing NFTs and $\mathrm{A} \beta$ plaques in the hippocampus may bind to HSV-1 via HSPGs, perhaps to advance AD progression. Indeed, the heparin-binding domain of $\mathrm{A} \beta$ oligomers has been shown to bind to HSV-1 glycoproteins, which entrapped and neutralized HSV-1 to prevent encephalitis in mice, but at the consequence of increased $A \beta 42$ accumulation (Eimer et al., 2018). Conversely, HSV-1 infection has been shown to form a protein corona layer that bound to amyloidogenic peptides and catalyzed A $\beta 42$ accumulation in the hippocampus and cortex of mice (Ezzat et al., 2019). Taken together, HSPGs-mediated interactions between HSV- 1 and A $\beta$ peptides at the NSCs-rich hippocampus may initiate and/or facilitate $\mathrm{AD}$ neurodegenerative processes.

\section{Inadequate Antiviral Immunity}

NPCs have also been found to be susceptible to HSV-1 infection and latency establishment in murine and neuronal 3D models (Menendez et al., 2016; Zheng et al., 2020). In cultured NPCs, HSV-1 infection decreased neuronal survival, which was prevented in co-cultures of NPCs with microglia (Chucair-Elliott et al., 2014). This protective effect can be reversed by the addition of IL-6-specific neutralizing antibodies. Likewise, exposing NPCs to recombinant IL-6 demonstrated similar protective effects against HSV-1 infection (Chucair-Elliott et al., 2014). IL-6 activation has also been associated with increased in vivo resistance against HSV-1 infection (Carr and Campbell, 1999; LeBlanc et al., 1999a). Immunohistochemical analyses have revealed that IL-6 expression was localized in the ventricles and lesser in other areas, including the hippocampus, 
in mice (Aniszewska et al., 2015). Hence, the low protein levels of IL-6 in the hippocampus may not provide sufficient antiviral immunity against $\mathrm{HSV}-1$ infection.

Microglia have been identified as the primary activator of cyclic GMP-AMP synthase-stimulator of interferon genes (cGAS-STING)-dependent type I interferon antiviral defense against HSV-1. Specifically, mice deficient in cGAS or STING showed impaired microglial type I interferon responses and elevated HSV-1 replication in the brain, leading to increased vulnerability to HSE (Reinert et al., 2016). A genome-wide study analyzing the microglia immunophenotype in the adult mice brain found that the immune vigilance (e.g., antiviral interferon activities) of hippocampal microglia was more robust than other brain areas. Interestingly, the hippocampal microglia were most vulnerable to age-related decline in immune function (Grabert et al., 2016). HSV-1 might become opportunistic as a result, targeting the hippocampus when microglial immunosurveillance weakens. This is consistent with the findings that senescence or aged microglia often preceded AD-related neuropathology in the brain, including the hippocampus (Kaneshwaran et al., 2019; Rodriguez-Callejas et al., 2020), as also reviewed in Streit et al. (2009). Henceforth, specific antiviral immunity against HSV-1 might be inadequate in brain regions susceptible to HSV1 infection. Kramer and Enquist (2013) also hypothesized that not all cells of the nervous system are equally prone to HSV-1 infection due to variations of immune defenses involved.

\section{High Expression of Glucocorticoid Receptor (GR)}

In the mammalian brain, high GR expression has been found in the hippocampus throughout life (Reul et al., 1989; Wang et al., 2013). Hence, the hippocampus is known to be highly vulnerable to glucocorticoid- or stress-related pathology, as reviewed in McEwen et al. (2016). Activated GR is known to interact with viral promoters to facilitate viral replication and infectivity in the brain (Fouty and Solodushko, 2011). The HSV-1 genome has several GR response elements that have been shown to stimulate viral promoters (i.e., VP16 and ICP0) to initiate reactivation and replication (Harrison et al., 2019; Ostler et al., 2019). These studies further demonstrated that GR antagonists prevented HSV-1 shedding in neuronal cells and reactivation in mice (Harrison et al., 2019; Ostler et al., 2019). Inhibiting glucocorticoid synthesis with cyanoketone also inhibited HSV1 reactivation in mice (Noisakran et al., 1998). In contrast, dexamethasone (i.e., synthetic glucocorticoid) treatment has been shown to induce HSV-1 reactivation and replication in vitro and in vivo (Sawiris et al., 1994; Halford et al., 1996; Hardwicke and Schaffer, 1997; Noisakran et al., 1998; Erlandsson et al., 2002; Du et al., 2012; Harrison et al., 2019). Therefore, the hippocampus has a prominent GR expression that could promote HSV-1 virulence in the CNS.

\section{High Expression of Amyloid Precursor Protein (APP)}

HSV-1 infection has been shown to upregulate enzymes that cleave APP following the amylogenic pathway to generate
A $340 / 42$ peptides (Wozniak et al., 2007; De Chiara et al., 2010; Piacentini et al., 2015). APP is ubiquitously expressed in the brain, with higher expression found in the olfactory system, cerebral cortex and hippocampus (Card et al., 1988; Imaizumi et al., 1993). These areas are also known to be targeted by HSV-1 (Table 1). HSV-1 capsids have been shown to bind to APP to expedite viral transport in both squid and epithelial cell culture models (Satpute-Krishnan et al., 2003; Cheng et al., 2011). The infected epithelial cells further displayed abnormal APP processing, resulting in mislocalized APP that may contribute to AD (Cheng et al., 2011).

Recent studies have also demonstrated that HSV-1 infection induced $\mathrm{A} \beta 42$ or $\mathrm{A} \beta 40 / 42$ accumulation, indicative of pathological APP metabolism, in the hippocampus in vitro and in vivo (De Chiara et al., 2019; Ezzat et al., 2019; PowellDoherty et al., 2020). Interestingly, $A \beta 40 / 42$ accumulation was observed in the hippocampus in a mouse model of HSV-1 reactivation, but such neuropathology did not occur in mice with APP gene knockout (Li Puma et al., 2019). Thus, APP appears imperative for the cellular propagation and spread of HSV-1, generating $A \beta 40 / 42$ peptides in the process. This might also contribute to the hippocampal susceptibility to HSV-1 infection, given that the hippocampus has high APP expression.

\section{CONCLUDING REMARKS}

The review discussed the interplay between HSV-1 and hippocampal- or memory-related brain disorders, namely AD and aMCI/MCI. Next, this review outlined the theoretical pathway by which HSV-1 productive infection or reactivation infiltrates the brain, underscoring its predilection for the limbic system and the hippocampus therein. HSV-1 likely induces neuropathological effects in the hippocampus comparable to AD phenotype. Given the established role of the hippocampus in learning and memory, aMCI/MCI likely precede $\mathrm{AD}$ in the course of disease development in persistent or recurrent HSV1 infection.

Factors and mechanisms contributing to the hippocampal susceptibility to HSV-1 infection are also elucidated. Several $2 \mathrm{D}$ and $3 \mathrm{D}$ cell culture studies reported the use of antiherpetic agents to prevent HSV-1-induced AD-related neuropathology, including hippocampal damage (Ando et al., 2008; Wozniak et al., 2011, 2013; Cairns et al., 2020). This is consistent with three large retrospective cohort studies spanning multiple countries showing that antiherpetic agents (e.g., acyclovir and valacyclovir) were associated with a reduced risk of dementia (Tzeng et al., 2018; Lopatko Lindman et al., 2021; Schnier et al., 2021). However, observational cohort studies can only inform associations, not causation. To this end, an on-going 78-week phase II randomized placebo-controlled clinical trial is assessing the efficacy of valacyclovir in attenuating symptom progression in patients with mild AD with HSV-1 seropositivity (Devanand et al., 2020). This is the first trial to investigate whether antiviral has any causal role in treating AD (Devanand et al., 2020).

It is still unknown whether the risk of $\mathrm{AD}$ development or progression would remain attenuated should antiviral 
agents be discontinued as $\mathrm{HSV}-1$ may reactivate thereafter. Current antiherpetic agents only inhibit HSV-1 replication and do not eradicate HSV-1 latency (LeBlanc et al., 1999b; Sawtell et al., 2001). Hence, HSV-1 may reside permanently in the nervous system amongst those infected, with their hippocampal function at risk for HSV-1 infection. More research could be conducted on potential treatments that may attenuate or prevent HSV-1-induced neuropathology. For one, the optimal drug dosage, frequency and duration of antiherpetic agents in treating AD should be determined, in light of HSV-1 latency. No vaccines are available for HSV-1 to date, suggesting further research on vaccine design and development to be considered (Whitley and Baines, 2018). Multiple phase II/III clinical trials investigating $\mathrm{A} \beta$-based therapies (e.g., secretase inhibitors and monoclonal antibodies) for AD have been unsuccessful, as reviewed in Oxford et al. (2020). A possible reason for this could be an on-going HSV-1 infection or reactivation that may promote the formation or prevent the clearance of $A \beta 40 / 42$ in the brain, especially in the hippocampus. Therefore, synergistic antiherpetic agent with $\mathrm{A} \beta$-based therapy may show promise in treating AD.

All in all, persistent HSV-1 infection and reactivation may present as risk factors, which likely interacts with and adds to other risk factors (e.g., age, ApoE4 genotype and other microbial infections) in the development of $\mathrm{AD}$ and other hippocampalrelated brain disorders, as reviewed in Wainberg et al. (2021)

\section{REFERENCES}

Abrahamson, E. E., Zheng, W., Muralidaran, V., Ikonomovic, M. D., Bloom, D. C., Nimgaonkar, V. L., et al. (2020). Modeling Abeta42 accumulation in response to herpes simplex virus 1 infection: 2D or 3D? J. Virol. 95, e2219-e2220.

Agostini, S., Costa, A. S., Mancuso, R., Guerini, F. R., Nemni, R., and Clerici, M. (2019). The PILRA G78R variant correlates with higher HSV-1-Specific IgG titers in Alzheimer's disease. Cell Mol. Neurobiol. 39, 1217-1221. doi: 10.1007/s10571-019-00712-5

Agostini, S., Mancuso, R., Baglio, F., Cabinio, M., Hernis, A., Costa, A. S., et al. (2016a). High avidity HSV-1 antibodies correlate with absence of amnestic Mild cognitive impairment conversion to Alzheimer's disease. Brain Behav. Immun. 58, 254-260. doi: 10.1016/j.bbi.2016.07.153

Agostini, S., Mancuso, R., Baglio, F., Cabinio, M., Hernis, A., Guerini, F. R., et al. (2016b). Lack of evidence for a role of HHV-6 in the pathogenesis of Alzheimer's disease. J. Alzheimers Dis. 49, 229-235. doi: 10.3233/jad- 150464

Aiello, A. E., Haan, M., Blythe, L., Moore, K., Gonzalez, J. M., and Jagust, W. (2006). The influence of latent viral infection on rate of cognitive decline over 4 years. J. Am. Geriatr. Soc. 54, 1046-1054. doi: 10.1111/j.1532-5415.2006.00796.x

Altman, J., and Das, G. D. (1965). Autoradiographic and histological evidence of postnatal hippocampal neurogenesis in rats. J. Comp. Neurol. 124, 319-335. doi: 10.1002/cne.901240303

Alvarez, G., Aldudo, J., Alonso, M., Santana, S., and Valdivieso, F. (2012). Herpes simplex virus type 1 induces nuclear accumulation of hyperphosphorylated tau in neuronal cells. J. Neurosci. Res. 90, 1020-1029. doi: 10.1002/jnr.23003

Alzheimer's Association. (2021). 2021 Alzheimer's disease facts and figures. Alzheimers Dement. 17, 327-406. doi: 10.1002/alz.12328

Anand, K. S., and Dhikav, V. (2012). Hippocampus in health and disease: an overview. Ann. Indian Acad. Neurol. 15, 239-246. doi: 10.4103/0972-2327. 104323

Anderson, J. R., and Field, H. J. (1983). The distribution of herpes simplex type 1 antigen in mouse central nervous system after different routes of inoculation. J. Neurol. Sci. 60, 181-195. doi: 10.1016/0022-510x(83)90061-8

Ando, Y., Kitayama, H., Kawaguchi, Y., and Koyanagi, Y. (2008). Primary target cells of herpes simplex virus type 1 in the hippocampus. Microbes Infect. 10, 1514-1523. doi: 10.1016/j.micinf.2008.09.005 and Vigasova et al. (2021). However, there is no evidence of causation in humans yet as HSV-1 reactivation cannot be measured in the living brain, as Mancuso et al. (2019) suggested. Although only AD and aMCI/MCI neuropathogenesis have been strongly linked to HSV-1, HSV-1 may also be involved in other hippocampal-related brain disorders, such as schizophrenia, depression, anxiety and post-traumatic stress disorder (Small et al., 2011; Anand and Dhikav, 2012; Klein, 2017). This possibly adds on to the list of established diseases caused by HSV-1, namely mucocutaneous lesions and encephalitis (Figure 2).

\section{AUTHOR CONTRIBUTIONS}

SY wrote the manuscript. SY, JC, and WL conceptualized and edited the manuscript. MY, ST, TS, and IP critically revised the manuscript. All authors read and approved the manuscript.

\section{FUNDING}

This work was supported by the Long Term Research Grant Scheme (LRGS) (LRGS/1/2019/SYUC/02/1/5) from the Ministry of Higher Education, Malaysia and Sunway University Individual Research Grant (GRTIN-IRG-23-2021).

Aniszewska, A., Chlodzinska, N., Bartkowska, K., Winnicka, M. M., Turlejski, K., and Djavadian, R. L. (2015). The expression of interleukin-6 and its receptor in various brain regions and their roles in exploratory behavior and stress responses. J. Neuroimmunol. 284, 1-9. doi: 10 . 1016/j.jneuroim.2015.05.001

Antinone, S. E., and Smith, G. A. (2010). Retrograde axon transport of herpes simplex virus and pseudorabies virus: a live-cell comparative analysis. J. Virol. 84, 1504-1512. doi: 10.1128/jvi.02029-09

Arii, J., Goto, H., Suenaga, T., Oyama, M., Kozuka-Hata, H., Imai, T., et al. (2010). Non-muscle myosin IIA is a functional entry receptor for herpes simplex virus-1. Nature 467, 859-862. doi: 10.1038/nature09420

Arii, J., Hirohata, Y., Kato, A., and Kawaguchi, Y. (2015). Nonmuscle myosin heavy chain IIb mediates herpes simplex virus 1 entry. J. Virol. 89, 1879-1888. doi: 10.1128/jvi.03079-14

Armangue, T., Spatola, M., Vlagea, A., Mattozzi, S., Cárceles-Cordon, M., Martinez-Heras, E., et al. (2018). Frequency, symptoms, risk factors, and outcomes of autoimmune encephalitis after herpes simplex encephalitis: a prospective observational study and retrospective analysis. Lancet Neurol. 17, $760-772$.

Armien, A. G., Hu, S., Little, M. R., Robinson, N., Lokensgard, J. R., Low, W. C., et al. (2010). Chronic cortical and subcortical pathology with associated neurological deficits ensuing experimental herpes encephalitis. Brain Pathol. 20, 738-750. doi: 10.1111/j.1750-3639.2009.00354.x

Atanasiu, D., Saw, W. T., Cohen, G. H., and Eisenberg, R. J. (2010). Cascade of events governing cell-cell fusion induced by herpes simplex virus glycoproteins gD, gH/gL, and gB. J. Virol. 84, 12292-12299. doi: 10.1128/jvi.01700-10

Ball, M. J. (1982). Limbic predilection in Alzheimer dementia: is reactivated herpesvirus involved? Can. J. Neurol. Sci. 9, 303-306. doi: 10.1017/ s0317167100044115

Ball, M. J., Lukiw, W. J., Kammerman, E. M., and Hill, J. M. (2013). Intracerebral propagation of Alzheimer's disease: strengthening evidence of a herpes simplex virus etiology. Alzheimers Dement. 9, 169-175. doi: 10.1016/j.jalz.2012.07.005

Barnes, L. L., Capuano, A. W., Aiello, A. E., Turner, A. D., Yolken, R. H., Torrey, E. F., et al. (2015). Cytomegalovirus infection and risk of Alzheimer disease in older black and white individuals. J. Infect. Dis. 211, 230-237. doi: 10.1093/ infdis/jiu437 
Barnett, E. M., Jacobsen, G., Evans, G., Cassell, M., and Perlman, S. (1994). Herpes simplex encephalitis in the temporal cortex and limbic system after trigeminal nerve inoculation. J. Infect. Dis. 169, 782-786. doi: 10.1093/infdis/169.4.782

Bearer, E. L. (2012). HSV, axonal transport and Alzheimer's disease: in vitro and in vivo evidence for causal relationships. Future Virol. 7, 885-899. doi: 10.2217/ fvl.12.81

Beers, D. R., Henkel, J. S., Kesner, R. P., and Stroop, W. G. (1995). Spatial recognition memory deficits without notable CNS pathology in rats following herpes simplex encephalitis. J. Neurol. Sci. 131, 119-127. doi: 10.1016/0022510x(95)00099-n

Beers, D. R., Henkel, J. S., Schaefer, D. C., Rose, J. W., and Stroop, W. G. (1993). Neuropathology of herpes simplex virus encephalitis in a rat seizure model. J. Neuropathol. Exp. Neurol. 52, 241-252. doi: 10.1097/00005072-19930500000008

Bignami, A., LeBlanc, A., and Perides, G. (1994). A role for extracellular matrix degradation and matrix metalloproteinases in senile dementia? Acta Neuropathol. 87, 308-312. doi: 10.1007/s004010050090

Boggian, I., Buzzacaro, E., Calistri, A., Calvi, P., Cavaggioni, A., Mucignat-Caretta, C., et al. (2000). Asymptomatic herpes simplex type 1 virus infection of the mouse brain. J. Neurovirol. 6, 303-313.

Braak, H., and Braak, E. (1991). Neuropathological stageing of Alzheimer-related changes. Acta Neuropathol. 82, 239-259. doi: 10.1007/bf00308809

Braun, E., Zimmerman, T., Hur, T. B., Reinhartz, E., Fellig, Y., Panet, A., et al. (2006). Neurotropism of herpes simplex virus type 1 in brain organ cultures. J. Gen. Virol. 87(Pt 10), 2827-2837. doi: 10.1099/vir.0.81850-0

Burgos, J. S., Ramirez, C., Guzman-Sanchez, F., Alfaro, J. M., Sastre, I., and Valdivieso, F. (2006). Hematogenous vertical transmission of herpes simplex virus type 1 in mice. J. Virol. 80, 2823-2831. doi: 10.1128/jvi.80.6.2823-2831. 2006

Cairns, D. M., Rouleau, N., Parker, R. N., Walsh, K. G., Gehrke, L., and Kaplan, D. L. (2020). A 3D human brain-like tissue model of herpes-induced Alzheimer's disease. Sci. Adv. 6:eaay8828. doi: 10.1126/sciadv.aay8828

Caparros-Lefebvre, D., Girard-Buttaz, I., Reboul, S., Lebert, F., Cabaret, M., Verier, A., et al. (1996). Cognitive and psychiatric impairment in herpes simplex virus encephalitis suggest involvement of the amygdalo-frontal pathways. J. Neurol. 243, 248-256. doi: 10.1007/bf00868522

Carbone, I., Lazzarotto, T., Ianni, M., Porcellini, E., Forti, P., Masliah, E., et al. (2014). Herpes virus in Alzheimer's disease: relation to progression of the disease. Neurobiol. Aging 35, 122-1294.

Card, J. P., Meade, R. P., and Davis, L. G. (1988). Immunocytochemical localization of the precursor protein for beta-amyloid in the rat central nervous system. Neuron 1, 835-846. doi: 10.1016/0896-6273(88)90131-6

Carr, D. J., and Campbell, I. L. (1999). Transgenic expression of interleukin-6 in the central nervous system confers protection against acute herpes simplex virus type-1 infection. J. Neurovirol. 5, 449-457. doi: 10.3109/13550289909045373

Chen, S. H., Yao, H. W., Huang, W. Y., Hsu, K. S., Lei, H. Y., Shiau, A. L., et al. (2006). Efficient reactivation of latent herpes simplex virus from mouse central nervous system tissues. J. Virol. 80, 12387-12392. doi: 10.1128/jvi.01232-06

Cheng, S.-B., Ferland, P., Webster, P., and Bearer, E. L. (2011). Herpes simplex virus dances with amyloid precursor protein while exiting the cell. PLoS One 6:e0017966.

Chucair-Elliott, A. J., Conrady, C., Zheng, M., Kroll, C. M., Lane, T. E., and Carr, D. J. (2014). Microglia-induced IL-6 protects against neuronal loss following HSV-1 infection of neural progenitor cells. Glia 62, 1418-1434. doi: 10.1002/ glia.22689

Costa, A. S., Agostini, S., Guerini, F. R., Mancuso, R., Clerici, M., and Pandey, J. P. (2020). Relation between FCGRIIB rs1050501 and HSV-1 specific IgG antibodies in Alzheimer's disease. J. Transl. Med. 18:325.

Costa, A. S., Agostini, S., Guerini, F. R., Mancuso, R., Zanzottera, M., Ripamonti, E., et al. (2017). Modulation of immune responses to herpes simplex virus type 1 by IFNL3 and IRF7 polymorphisms: a study in Alzheimer's disease. J. Alzheimers Dis. 60, 1055-1063. doi: 10.3233/jad-170520

Dagsdottir, H. M., Sigurethardottir, B., Gottfreethsson, M., Kristjansson, M., Love, A., Baldvinsdottir, G. E., et al. (2014). Herpes simplex encephalitis in Iceland 1987-2011. Springerplus 3:524. doi: 10.1186/2193-1801-3-524

Damasio, A. R., and Van Hoesen, G. W. (1985). The limbic system and the localisation of herpes simplex encephalitis. J. Neurol. Neurosurg. Psychiatry 48, 297-301. doi: 10.1136/jnnp.48.4.297
Darougar, S., Wishart, M. S., and Viswalingam, N. D. (1985). Epidemiological and clinical features of primary herpes simplex virus ocular infection. Br. J. Ophthalmol. 69, 2-6. doi: 10.1136/bjo.69.1.2

De Chiara, G., Marcocci, M. E., Civitelli, L., Argnani, R., Piacentini, R., Ripoli, C., et al. (2010). APP processing induced by herpes simplex virus type 1 (HSV1) yields several APP fragments in human and rat neuronal cells. PLoS One 5:e0013989.

De Chiara, G., Piacentini, R., Fabiani, M., Mastrodonato, A., Marcocci, M. E., Limongi, D., et al. (2019). Recurrent herpes simplex virus-1 infection induces hallmarks of neurodegeneration and cognitive deficits in mice. PLoS Pathog. 15:e1007617. doi: 10.1371/journal.ppat.1007617

Deatly, A. M., Spivack, J. G., Lavi, E., O’Boyle, D. R., and Fraser, N. W. (1988). Latent herpes simplex virus type 1 transcripts in peripheral and central nervous system tissues of mice map to similar regions of the viral genome. J. Virol. 62, 749-756. doi: 10.1128/jvi.62.3.749-756.1988

Deshmane, S. L., and Fraser, N. W. (1989). During latency, herpes simplex virus type 1 DNA is associated with nucleosomes in a chromatin structure. J. Virol. 63, 943-947. doi: 10.1128/jvi.63.2.943-947.1989

Devanand, D. P., Andrews, H., Kreisl, W. C., Razlighi, Q., Gershon, A., Stern, Y., et al. (2020). Antiviral therapy: valacyclovir treatment of Alzheimer's disease (VALAD) trial: protocol for a randomised, double-blind,placebo-controlled, treatment trial. BMJ Open 10:e032112. doi: 10.1136/bmjopen-2019-032112

Dickerson, F. B., Boronow, J. J., Stallings, C., Origoni, A. E., Ruslanova, I., and Yolken, R. H. (2003). Association of serum antibodies to herpes simplex virus 1 with cognitive deficits in individuals with schizophrenia. Arch. Gen. Psychiatry 60, 466-472. doi: 10.1001/archpsyc.60.5.466

Dickerson, F., Stallings, C., Sullens, A., Origoni, A., Leister, F., Krivogorsky, B., et al. (2008). Association between cognitive functioning, exposure to Herpes Simplex Virus type 1, and the COMT Val158Met genetic polymorphism in adults without a psychiatric disorder. Brain Behav. Immun. 22, 1103-1107. doi: 10.1016/j.bbi.2008.04.156

Dinn, J. J. (1979). Distribution of herpes simplex virus in acute necrotising encephalitis. J. Pathol. 129, 135-138. doi: 10.1002/path.1711290305

Dohner, K., Wolfstein, A., Prank, U., Echeverri, C., Dujardin, D., Vallee, R., et al. (2002). Function of dynein and dynactin in herpes simplex virus capsid transport. Mol. Biol. Cell 13, 2795-2809. doi: 10.1091/mbc.01-07-0348

Du, T., Zhou, G., and Roizman, B. (2012). Induction of apoptosis accelerates reactivation of latent HSV-1 in ganglionic organ cultures and replication in cell cultures. Proc. Natl. Acad. Sci. U.S.A. 109, 14616-14621. doi: 10.1073/pnas. 1212661109

Duarte, L. F., Farias, M. A., Alvarez, D. M., Bueno, S. M., Riedel, C. A., and Gonzalez, P. A. (2019). Herpes simplex virus type 1 infection of the central nervous system: insights into proposed interrelationships with neurodegenerative disorders. Front. Cell Neurosci. 13:46.

Eimer, W. A., Vijaya Kumar, D. K., Navalpur Shanmugam, N. K., Rodriguez, A. S., Mitchell, T., Washicosky, K. J., et al. (2018). Alzheimer's disease-associated betaAmyloid is rapidly seeded by herpesviridae to protect against brain infection. Neuron 99:e53.

Eriksson, P. S., Perfilieva, E., Bjork-Eriksson, T., Alborn, A. M., Nordborg, C., Peterson, D. A., et al. (1998). Neurogenesis in the adult human hippocampus. Nat. Med. 4, 1313-1317.

Erlandsson, A. C., Bladh, L. G., Stierna, P., Yucel-Lindberg, T., Hammarsten, O., Modeer, T., et al. (2002). Herpes simplex virus type 1 infection and glucocorticoid treatment regulate viral yield, glucocorticoid receptor and NFkappaB levels. J. Endocrinol. 175, 165-176. doi: 10.1677/joe.0.1750165

Esiri, M. M. (1982a). Herpes simplex encephalitis. An immunohistological study of the distribution of viral antigen within the brain. J. Neurol. Sci. 54, 209-226.

Esiri, M. M. (1982b). Viruses and Alzheimer's disease. J. Neurol. Neurosurg. Psychiatry 45, 759-760.

Ezzat, K., Pernemalm, M., Palsson, S., Roberts, T. C., Jarver, P., Dondalska, A., et al. (2019). The viral protein corona directs viral pathogenesis and amyloid aggregation. Nat. Commun. 10:2331.

Fewster, P. H., Griffin-Brooks, S., MacGregor, J., Ojalvo-Rose, E., and Ball, M. J. (1991). A topographical pathway by which histopathological lesions disseminate through the brain of patients with Alzheimer's disease. Dementia 2, 121-132. doi: 10.1159/000107187

Fouty, B., and Solodushko, V. (2011). "The glucocorticoid receptor in retroviral infection," in Viral Gene Therapy, ed. K. Xu (IntechOpen). doi: 10.5772/21722 
Fruchter, E., Goldberg, S., Fenchel, D., Grotto, I., Ginat, K., and Weiser, M. (2015). The impact of Herpes simplex virus type 1 on cognitive impairments in young, healthy individuals - A historical prospective study. Schizophr. Res. 168, 292-296. doi: 10.1016/j.schres.2015.08.036

Gannicliffe, A., Sutton, R. N., and Itzhaki, R. F. (1986). Viruses, brain and immunosuppression. Psychol. Med. 16, 247-249. doi: 10.1017/ s0033291700009053

George, B. P., Schneider, E. B., and Venkatesan, A. (2014). Encephalitis hospitalization rates and inpatient mortality in the United States, 2000-2010. PLoS One 9:e104169. doi: 10.1371/journal.pone.0104169

Geraghty, R. J., Krummenacher, C., Cohen, G. H., Eisenberg, R. J., and Spear, P. G. (1998). Entry of alphaherpesviruses mediated by poliovirus receptor-related protein 1 and poliovirus receptor. Science 280, 1618-1620. doi: 10.1126/science. 280.5369 .1618

Grabert, K., Michoel, T., Karavolos, M. H., Clohisey, S., Baillie, J. K., Stevens, M. P., et al. (2016). Microglial brain region-dependent diversity and selective regional sensitivities to aging. Nat. Neurosci. 19, 504-516. doi: 10.1038/nn.4222

Granerod, J., Ambrose, H. E., Davies, N. W. S., Clewley, J. P., Walsh, A. L., Morgan, D., et al. (2010). Causes of encephalitis and differences in their clinical presentations in England: a multicentre, population-based prospective study. Lancet Infect. Dis. 10, 835-844. doi: 10.1016/s1473-3099(10)70222-x

Granzow, H., Klupp, B. G., Fuchs, W., Veits, J., Osterrieder, N., and Mettenleiter, T. C. (2001). Egress of alphaherpesviruses: comparative ultrastructural study. J. Virol. 75, 3675-3684. doi: 10.1128/jvi.75.8.3675-3684.2001

Grunewald, K., Desai, P., Winkler, D. C., Heymann, J. B., Belnap, D. M., Baumeister, W., et al. (2003). Three-dimensional structure of herpes simplex virus from cryo-electron tomography. Science 302, 1396-1398. doi: 10.1126/ science. 1090284

Haarr, L., Shukla, D., Rodahl, E., Dal Canto, M. C., and Spear, P. G. (2001). Transcription from the gene encoding the herpesvirus entry receptor nectin-1 (HveC) in nervous tissue of adult mouse. Virology 287, 301-309. doi: 10.1006/ viro.2001.1041

Hagihara, K., Watanabe, K., Chun, J., and Yamaguchi, Y. (2000). Glypican-4 is an FGF2-binding heparan sulfate proteoglycan expressed in neural precursor cells. Dev. Dyn. 219, 353-367. doi: 10.1002/1097-0177(2000)9999:9999<::aiddvdy1059>3.0.co;2-\#

Halford, W. P., Gebhardt, B. M., and Carr, D. J. (1996). Mechanisms of herpes simplex virus type 1 reactivation. J. Virol. 70, 5051-5060.

Hamdani, N., Daban-Huard, C., Godin, O., Laouamri, H., Jamain, S., Attiba, D., et al. (2017). Effects of cumulative herpesviridae and Toxoplasma gondii infections on cognitive function in healthy, bipolar, and Schizophrenia subjects. J. Clin. Psychiatry 78, e18-e27.

Hardwicke, M. A., and Schaffer, P. A. (1997). Differential effects of nerve growth factor and dexamethasone on herpes simplex virus type 1 oriL- and oriSdependent DNA replication in PC12 cells. J. Virol. 71, 3580-3587. doi: 10.1128/ jvi.71.5.3580-3587.1997

Harfouche, M., Chemaitelly, H., and Abu-Raddad, L. J. (2019). Herpes simplex virus type 1 epidemiology in Africa: systematic review, meta-analyses, and meta-regressions. J. Infect. 79, 289-299. doi: 10.1016/j.jinf.2019.07.012

Harris, L., Griem, J., Gummery, A., Marsh, L., Defres, S., Bhojak, M., et al. (2020). Neuropsychological and psychiatric outcomes in encephalitis: a multi-centre case-control study. PLoS One 15:e230436. doi: 10.1371/journal.pone.0230436

Harris, S. A., and Harris, E. A. (2018). Molecular mechanisms for herpes simplex virus type 1 pathogenesis in Alzheimer's disease. Front. Aging Neurosci. 10:48.

Harrison, K. S., Zhu, L., Thunuguntla, P., and Jones, C. (2019). Antagonizing the glucocorticoid receptor impairs explant-induced reactivation in mice latently infected with herpes simplex virus 1. J. Virol. 93, e418-e419.

He, J., Cosby, R., Hill, J. M., and Bazan, H. E. (2017). Changes in corneal innervation after HSV-1 latency established with different reactivation phenotypes. Curr. Eye Res. 42, 181-186. doi: 10.3109/02713683.2016.1167919

Hemling, N., Roytta, M., Rinne, J., Pollanen, P., Broberg, E., Tapio, V., et al. (2003). Herpesviruses in brains in Alzheimer's and Parkinson's diseases. Ann. Neurol. $54,267-271$.

Hemmingsson, E. S., Hjelmare, E., Weidung, B., Olsson, J., Josefsson, M., Adolfsson, R., et al. (2021). Antiviral treatment associated with reduced risk of clinical Alzheimer's disease-a nested case-control study. Alzheimer's Dement. Trans. Res. Clin. Interv. 7:e12187.
Herold, B. C., Visalli, R. J., Susmarski, N., Brandt, C. R., and Spear, P. G. (1994). Glycoprotein C-independent binding of herpes simplex virus to cells requires cell surface heparan sulphate and glycoprotein B. J. Gen. Virol. 75(Pt 6), 1211-1222. doi: 10.1099/0022-1317-75-6-1211

Herold, B. C., WuDunn, D., Soltys, N., and Spear, P. G. (1991). Glycoprotein C of herpes simplex virus type 1 plays a principal role in the adsorption of virus to cells and in infectivity. J. Virol. 65, 1090-1098. doi: 10.1128/jvi.65.3.1090-1098. 1991

Honess, R. W., and Roizman, B. (1974). Regulation of herpesvirus macromolecular synthesis. I. cascade regulation of the synthesis of three groups of viral proteins. J. Virol. 14, 8-19. doi: 10.1128/jvi.14.1.8-19.1974

Horvath, S., Prandovszky, E., Kis, Z., Krummenacher, C., Eisenberg, R. J., Cohen, G. H., et al. (2006). Spatiotemporal changes of the herpes simplex virus entry receptor nectin-1 in murine brain during postnatal development. J. Neurovirol. 12, 161-170. doi: 10.1080/13550280600760594

Hu, K., Wang, Y., Chen, K., Hou, L., and Zhang, X. (2016). Multi-scale features extraction from baseline structure MRI for MCI patient classification and $\mathrm{AD}$ early diagnosis. Neurocomputing 175, 132-145. doi: 10.1016/j.neucom.2015.10. 043

Hufner, K., Horn, A., Derfuss, T., Glon, C., Sinicina, I., Arbusow, V., et al. (2009). Fewer latent herpes simplex virus type 1 and cytotoxic $\mathrm{T}$ cells occur in the ophthalmic division than in the maxillary and mandibular divisions of the human trigeminal ganglion and nerve. J. Virol. 83, 3696-3703. doi: 10.1128/ jvi.02464-08

Hutchinson, L., and Johnson, D. C. (1995). Herpes simplex virus glycoprotein K promotes egress of virus particles. J. Virol. 69, 5401-5413. doi: 10.1128/jvi.69.9. 5401-5413.1995

Hutto, C., Arvin, A., Jacobs, R., Steele, R., Stagno, S., Lyrene, R., et al. (1987). Intrauterine herpes simplex virus infections. J. Pediatr. 110, 97-101.

Imaizumi, K., Iwata, H., Yoshida, S., Sun, G., Okumura, N., and Shiosaka, S. (1993). Coexistence of amyloid beta-protein precursor and basic fibroblast growth factor in single cells of the rat parietal cortex, hippocampus and basal magnocellular nucleus. J. Chem. Neuroanat. 6, 159-165. doi: 10.1016/08910618(93)90025-y

Itzhaki, R. F. (2014). Herpes simplex virus type 1 and Alzheimer's disease: increasing evidence for a major role of the virus. Front. Aging Neurosci. 6:202.

Itzhaki, R. F., and Klapper, P. (2014). Cytomegalovirus: an improbable cause of Alzheimer disease. J. Infect. Dis. 209, 972-973. doi: 10.1093/infdis/jit665

Itzhaki, R. F., Lathe, R., Balin, B. J., Ball, M. J., Bearer, E. L., Braak, H., et al. (2016). Microbes and Alzheimer's disease. J. Alzheimers Dis. 51, 979-984.

Itzhaki, R. F., Lin, W. R., Shang, D., Wilcock, G. K., Faragher, B., and Jamieson, G. A. (1997). Herpes simplex virus type 1 in brain and risk of Alzheimer's disease. Lancet 349, 241-244. doi: 10.1016/s0140-6736(96)10149-5

Jack, C. R., Petersen, R. C., Xu, Y. C., O'Brien, P. C., Smith, G. E., Ivnik, R. J., et al. (1999). Prediction of AD with MRI-based hippocampal volume in mild cognitive impairment. Neurology 52, 1397-1403. doi: 10.1212/wnl.52.7.1397

Jamieson, G. A., Maitland, N. J., Wilcock, G. K., Craske, J., and Itzhaki, R. F. (1991). Latent herpes simplex virus type 1 in normal and Alzheimer's disease brains. J. Med. Virol. 33, 224-227. doi: 10.1002/jmv.1890330403

Jamieson, G. A., Maitland, N. J., Wilcock, G. K., Yates, C. M., and Itzhaki, R. F. (1992). Herpes simplex virus type 1 DNA is present in specific regions of brain from aged people with and without senile dementia of the Alzheimer type. J. Pathol. 167, 365-368. doi: 10.1002/path.1711670403

Jennische, E., Eriksson, C. E., Lange, S., Trybala, E., and Bergstrom, T. (2015). The anterior commissure is a pathway for contralateral spread of herpes simplex virus type 1 after olfactory tract infection. J. Neurovirol. 21, 129-147. doi: 10.1007/s13365-014-0312-0

Jonker, I., Klein, H. C., Duivis, H. E., Yolken, R. H., Rosmalen, J. G., and Schoevers, R. A. (2014). Association between exposure to HSV1 and cognitive functioning in a general population of adolescents. the TRAILS study. PLoS One 9:e101549. doi: 10.1371/journal.pone.0101549

Kaneshwaran, K., Olah, M., Tasaki, S., Yu, L., Bradshaw, E. M., Schneider, J. A., et al. (2019). Sleep fragmentation, microglial aging, and cognitive impairment in adults with and without Alzheimer's dementia. Sci. Adv. 5:eaax7331. doi: 10.1126/sciadv.aax7331

Kapur, N., Barker, S., Burrows, E. H., Ellison, D., Brice, J., Illis, L. S., et al. (1994). Herpes simplex encephalitis: long term magnetic resonance imaging 
and neuropsychological profile. J. Neurol. Neurosurg. Psychiatry 57, 1334-1342. doi: 10.1136/jnnp.57.11.1334

Karasneh, G. A., and Shukla, D. (2011). Herpes simplex virus infects most cell types in vitro: clues to its success. Virol. J. 8:481.

Khadr, L., Harfouche, M., Omori, R., Schwarzer, G., Chemaitelly, H., and AbuRaddad, L. J. (2019). The epidemiology of herpes simplex virus type 1 in Asia: systematic review, meta-analyses, and meta-regressions. Clin. Infect. Dis. 68, 757-772. doi: 10.1093/cid/ciy562

Kim, J. Y., Mandarino, A., Chao, M. V., Mohr, I., and Wilson, A. C. (2012). Transient reversal of episome silencing precedes VP16-dependent transcription during reactivation of latent HSV-1 in neurons. PLoS Pathog. 8:e1002540. doi: 10.1371/journal.ppat. 1002540

Klein, H. C. (2017). Silencing of viral elements: an available cure for schizophrenia? Front. Psychiatry 8:284.

Kobayashi, N., Nagata, T., Shinagawa, S., Oka, N., Shimada, K., Shimizu, A., et al. (2013). Increase in the IgG avidity index due to herpes simplex virus type 1 reactivation and its relationship with cognitive function in amnestic mild cognitive impairment and Alzheimer's disease. Biochem. Biophys. Res. Commun. 430, 907-911. doi: 10.1016/j.bbrc.2012.12.054

Kramer, T., and Enquist, L. W. (2013). Directional spread of alphaherpesviruses in the nervous system. Viruses 5, 678-707. doi: 10.3390/v5020678

Kubat, N. J., Tran, R. K., McAnany, P., and Bloom, D. C. (2004). Specific histone tail modification and not DNA methylation is a determinant of herpes simplex virus type 1 latent gene expression. J. Virol. 78, 1139-1149. doi: 10.1128/jvi.78. 3.1139-1149.2004

Kukhanova, M. K., Korovina, A. N., and Kochetkov, S. N. (2014). Human herpes simplex virus: life cycle and development of inhibitors. Biochemistry 79, 1635 1652. doi: 10.1134/s0006297914130124

Kwong, A. D., and Frenkel, N. (1987). Herpes simplex virus-infected cells contain a function(s) that destabilizes both host and viral mRNAs. Proc. Natl. Acad. Sci. U.S.A. 84, 1926-1930. doi: 10.1073/pnas.84.7.1926

Lathe, R., and Haas, J. G. (2017). Distribution of cellular HSV-1 receptor expression in human brain. J. Neurovirol. 23, 376-384. doi: 10.1007/s13365-016-0504-x

LeBlanc, R. A., Pesnicak, L., Cabral, E. S., Godleski, M., and Straus, S. E. (1999a). Lack of interleukin-6 (IL-6) enhances susceptibility to infection but does not alter latency or reactivation of herpes simplex virus type 1 in IL-6 knockout mice. J. Virol. 73, 8145-8151. doi: 10.1128/jvi.73.10.8145-8151.1999

LeBlanc, R. A., Pesnicak, L., Godleski, M., and Straus, S. E. (1999b). The comparative effects of famciclovir and valacyclovir on herpes simplex virus type 1 infection, latency, and reactivation in mice. J. Infect. Dis. 180, 594-599. doi: $10.1086 / 314962$

Lerchundi, R., Neira, R., Valdivia, S., Vio, K., Concha, M. I., Zambrano, A., et al. (2011). Tau cleavage at D421 by caspase- 3 is induced in neurons and astrocytes infected with herpes simplex virus type 1. J. Alzheimers Dis. 23, 513-520. doi: 10.3233/jad-2010-101386

Letenneur, L., Pérès, K., Fleury, H., Garrigue, I., Barberger-Gateau, P., Helmer, C., et al. (2008). Seropositivity to herpes simplex virus antibodies and risk of Alzheimer's disease: a population-based cohort study. PLoS One 3:e0003637.

Lewandowski, G., Zimmerman, M. N., Denk, L. L., Porter, D. D., and Prince, G. A. (2002). Herpes simplex type 1 infects and establishes latency in the brain and trigeminal ganglia during primary infection of the lip in cotton rats and mice. Arch. Virol. 147, 167-179. doi: 10.1007/s705-002-8309-9

Li Puma, D. D., Piacentini, R., Leone, L., Gironi, K., Marcocci, M. E., De Chiara, G., et al. (2019). Herpes simplex virus type-1 infection impairs adult hippocampal neurogenesis via amyloid-beta protein accumulation. Stem Cells 37, 1467-1480. doi: $10.1002 /$ stem.3072

Li, H., Habes, M., Wolk, D. A., Fan, Y., and Alzheimer's Disease Neuroimaging Initiative, and the Australian Imaging Biomarkers, and Lifestyle Study of Aging. (2019). A deep learning model for early prediction of Alzheimer's disease dementia based on hippocampal magnetic resonance imaging data. Alzheimers Dement. 15, 1059-1070. doi: 10.1016/j.jalz.2019.02.007

Li, L., Li, Z., Li, X., Wang, E., Lang, F., Xia, Y., et al. (2016). Reactivation of HSV-1 following explant of tree shrew brain. J. Neurovirol. 22, 293-306. doi: 10.1007/s13365-015-0393-4

Liedtke, W., Opalka, B., Zimmermann, C. W., and Lignitz, E. (1993). Age distribution of latent herpes simplex virus 1 and varicella-zoster virus genome in human nervous tissue. J. Neurol. Sci. 116, 6-11. doi: 10.1016/0022-510x(93) 90082-a
Lin, W. R., Shang, D., and Itzhaki, R. F. (1996). Neurotropic viruses and Alzheimer disease. interaction of herpes simplex type 1 virus and apolipoprotein $\mathrm{E}$ in the etiology of the disease. Mol. Chem. Neuropathol. 28, 135-141. doi: 10.1007/ bf02815215

Lin, W. R., Shang, D., Wilcock, G. K., and Itzhaki, R. F. (1995). Alzheimer's disease, herpes simplex virus type 1, cold sores and apolipoprotein E4. Biochem. Soc. Trans. 23:594S. doi: 10.1042/bst023594s

Linard, M., Letenneur, L., Garrigue, I., Doize, A., Dartigues, J. F., and Helmer, C. (2020). Interaction between APOE4 and herpes simplex virus type 1 in Alzheimer's disease. Alzheimers Dement. 16, 200-208. doi: 10.1002/alz.12008

Looker, K. J., Magaret, A. S., May, M. T., Turner, K. M., Vickerman, P., Gottlieb, S. L., et al. (2015). Global and regional estimates of prevalent and incident herpes simplex virus Type 1 infections in 2012. PLoS One 10:e0140765. doi: 10.1371/journal.pone.0140765

Lopatko Lindman, K., Hemmingsson, E. S., Weidung, B., Brannstrom, J., Josefsson, M., Olsson, J., et al. (2021). Herpesvirus infections, antiviral treatment, and the risk of dementia-a registry-based cohort study in Sweden. Alzheimers Dement. 7:e12119.

Lopatko Lindman, K., Weidung, B., Olsson, J., Josefsson, M., Kok, E., Johansson, A., et al. (2019). A genetic signature including apolipoprotein Eepsilon4 potentiates the risk of herpes simplex-associated Alzheimer's disease. Alzheimers Dement. 5, 697-704. doi: 10.1016/j.trci.2019.09.014

Lovheim, H., Gilthorpe, J., Adolfsson, R., Nilsson, L. G., and Elgh, F. (2015a). Reactivated herpes simplex infection increases the risk of Alzheimer's disease. Alzheimers Dement. 11, 593-599. doi: 10.1016/j.jalz.2014.04.522

Lovheim, H., Gilthorpe, J., Johansson, A., Eriksson, S., Hallmans, G., and Elgh, F. (2015b). Herpes simplex infection and the risk of Alzheimer's disease: a nested case-control study. Alzheimers Dement. 11, 587-592. doi: 10.1016/j.jalz.2014. 07.157

Lövheim, H., Norman, T., Weidung, B., Olsson, J., Josefsson, M., Adolfsson, R., et al. (2019). Herpes simplex virus, APOE $\varepsilon 4$, and cognitive decline in old age: results from the betula cohort study. J. Alzheimer's Dis. 67, 211-220. doi: $10.3233 /$ jad- 171162

Lovheim, H., Olsson, J., Weidung, B., Johansson, A., Eriksson, S., Hallmans, G., et al. (2018). Interaction between cytomegalovirus and herpes simplex virus type 1 associated with the risk of Alzheimer's disease development. J. Alzheimers Dis. 61, 939-945. doi: 10.3233/jad-161305

Lu, Y., Liu, C., Yu, D., Fawkes, S., Ma, J., Zhang, M., et al. (2021). Prevalence of mild cognitive impairment in community-dwelling Chinese populations aged over 55 years: a meta-analysis and systematic review. BMC Geriatr. 21:10.

Mancuso, R., Baglio, F., Agostini, S., Cabinio, M., Lagana, M. M., Hernis, A., et al. (2014a). Relationship between herpes simplex virus-1-specific antibody titers and cortical brain damage in Alzheimer's disease and amnestic mild cognitive impairment. Front. Aging Neurosci. 6:285.

Mancuso, R., Baglio, F., Cabinio, M., Calabrese, E., Hernis, A., Nemni, R., et al. (2014b). Titers of herpes simplex virus type 1 antibodies positively correlate with grey matter volumes in Alzheimer's disease. J. Alzheimers Dis. 38, 741-745. doi: 10.3233/jad-130977

Mancuso, R., Sicurella, M., Agostini, S., Marconi, P., and Clerici, M. (2019). Herpes simplex virus type 1 and Alzheimer's disease: link and potential impact on treatment. Expert Rev. Anti Infect. Ther. 17, 715-731. doi: 10.1080/14787210. 2019.1656064

Marcocci, M. E., Napoletani, G., Protto, V., Kolesova, O., Piacentini, R., Li Puma, D. D., et al. (2020). Herpes simplex virus-1 in the brain: the dark side of a sneaky infection. Trends Microbiol. 28, 808-820. doi: 10.1016/j.tim.2020.03.003

Marquez, L., Levy, M. L., Munoz, F. M., and Palazzi, D. L. (2011). A report of three cases and review of intrauterine herpes simplex virus infection. Pediatr. Infect. Dis. J. 30, 153-157. doi: 10.1097/inf.0b013e3181f55a5c

Martin, C., Aguila, B., Araya, P., Vio, K., Valdivia, S., Zambrano, A., et al. (2014). Inflammatory and neurodegeneration markers during asymptomatic HSV-1 reactivation. J. Alzheimers Dis. 39, 849-859. doi: 10.3233/jad-131706

McEwen, B. S., Nasca, C., and Gray, J. D. (2016). Stress effects on neuronal structure: Hippocampus, Amygdala, and prefrontal cortex. Neuropsychopharmacology 41, 3-23. doi: 10.1038/npp.2015.171

McFarland, D. J., and Hotchin, J. (1987). Contrasting patterns of virus spread and neuropathology following microinjection of herpes simplex virus into the hippocampus or cerebellum of mice. J. Neurol. Sci. 79, 255-265. doi: 10.1016/ 0022-510x(87)90233-4 
McFarland, D. J., Hotchin, J. E., and Baker, F. D. (1982). Binding of herpes simplex virus to regional areas of the rodent brain. J. Neurol. Sci. 56, 299-310. doi: 10.1016/0022-510x(82)90151-4

McLean, J. H., Shipley, M. T., Bernstein, D. I., and Corbett, D. (1993). Selective lesions of neural pathways following viral inoculation of the olfactory bulb. Exp. Neurol. 122, 209-222. doi: 10.1006/exnr.1993.1121

Menendez, C. M., and Carr, D. J. J. (2017). Herpes simplex virus-1 infects the olfactory bulb shortly following ocular infection and exhibits a longterm inflammatory profile in the form of effector and HSV-1-specific T cells. J. Neuroinflammation 14:124.

Menendez, C. M., Jinkins, J. K., and Carr, D. J. (2016). Resident T cells are unable to control herpes simplex virus-1 activity in the brain ependymal region during latency. J. Immunol. 197, 1262-1275. doi: 10.4049/jimmunol.1600207

Mettenleiter, T. C. (2002). Herpesvirus assembly and egress. J. Virol. 76, 1537-1547. doi: 10.1128/jvi.76.4.1537-1547.2002

Meyding-Lamade, U., Lamade, W., Kehm, R., Knopf, K. W., Hess, T., Gosztonyi, G., et al. (1998). Herpes simplex virus encephalitis: cranial magnetic resonance imaging and neuropathology in a mouse model. Neurosci. Lett. 248, 13-16. doi: 10.1016/s0304-3940(98)00319-x

Meyding-Lamade, U., Lamade, W., Kehm, R., Oberlinner, C., Fath, A., Wildemann, B., et al. (1999). Herpes simplex virus encephalitis: chronic progressive cerebral MRI changes despite good clinical recovery and low viral load - an experimental mouse study. Eur. J. Neurol. 6, 531-538. doi: 10.1046/j.1468-1331.1999.650531. $\mathrm{x}$

Miranda-Saksena, M., Boadle, R. A., Aggarwal, A., Tijono, B., Rixon, F. J., Diefenbach, R. J., et al. (2009). Herpes simplex virus utilizes the large secretory vesicle pathway for anterograde transport of tegument and envelope proteins and for viral exocytosis from growth cones of human fetal axons. J. Virol. 83, 3187-3199. doi: 10.1128/jvi.01579-08

Montgomery, R. I., Warner, M. S., Lum, B. J., and Spear, P. G. (1996). Herpes simplex virus-1 entry into cells mediated by a novel member of the TNF/NGF receptor family. Cell 87, 427-436. doi: 10.1016/s0092-8674(00)81363-x

Mori, I., Kimura, Y., Naiki, H., Matsubara, R., Takeuchi, T., Yokochi, T., et al. (2004). Reactivation of HSV-1 in the brain of patients with familial Alzheimer's disease. J. Med. Virol. 73, 605-611. doi: 10.1002/jmv.20133

Mori, I., Nishiyama, Y., Yokochi, T., and Kimura, Y. (2005). Olfactory transmission of neurotropic viruses. J. Neurovirol. 11, 129-137. doi: 10.1080/ 13550280590922793

Murphy, C. (2019). Olfactory and other sensory impairments in Alzheimer disease. Nat. Rev. Neurol. 15, 11-24. doi: 10.1038/s41582-018-0097-5

Murphy, M. J., Fani, L., Ikram, M. K., Ghanbari, M., and Ikram, M. A. (2021). Herpes simplex virus 1 and the risk of dementia: a population-based study. Sci. Rep. 11:8691.

Nimgaonkar, V. L., Yolken, R. H., Wang, T., Chang, C. C., McClain, L., McDade, E., et al. (2016). Temporal cognitive decline associated with exposure to infectious agents in a population-based, aging cohort. Alzheimer Dis. Assoc. Disord. 30, 216-222. doi: 10.1097/wad.0000000000000133

Noisakran, S., Halford, W. P., Veress, L., and Carr, D. J. (1998). Role of the hypothalamic pituitary adrenal axis and IL- 6 in stress-induced reactivation of latent herpes simplex virus type 1. J. Immunol. 160, 5441-5447.

Oikari, L. E., Okolicsanyi, R. K., Qin, A., Yu, C., Griffiths, L. R., and Haupt, L. M. (2016). Cell surface heparan sulfate proteoglycans as novel markers of human neural stem cell fate determination. Stem Cell Res. 16, 92-104. doi: 10.1016/j.scr.2015.12.011

Ostler, J. B., Harrison, K. S., Schroeder, K., Thunuguntla, P., and Jones, C. (2019). The Glucocorticoid Receptor (GR) stimulates herpes simplex virus 1 productive infection, in part because the infected cell protein 0 (ICP0) promoter is cooperatively transactivated by the gr and kruppel-like transcription factor 15 . J. Virol. 93:e2063-18.

Ou, Y. N., Zhu, J. X., Hou, X. H., Shen, X. N., Xu, W., Dong, Q., et al. (2020). Associations of infectious agents with alzheimer's disease: a systematic review and meta-analysis. J. Alzheimers Dis. 75, 299-309. doi: 10.3233/jad-191337

Overton, M., Pihlsgard, M., and Elmstahl, S. (2019). Prevalence and incidence of mild cognitive impairment across subtypes, age, and sex. Dement. Geriatr. Cogn. Disord. 47, 219-232. doi: 10.1159/000499763

Oxford, A. E., Stewart, E. S., and Rohn, T. T. (2020). Clinical trials in Alzheimer's disease: a hurdle in the path of remedy. Int. J. Alzheimers Dis. 2020:5380346.
Pais, R., Ruano, L., Carvalho, O. C., and Barros, H. (2020). Global cognitive impairment prevalence and incidence in community dwelling older adults-a systematic review. Geriatrics 5:84. doi: 10.3390/geriatrics5040084

Paivarinta, M. A., Roytta, M., Hukkanen, V., Marttila, R. J., and Rinne, U. K. (1994). Nervous system inflammatory lesions and viral nucleic acids in rabbits with herpes simplex virus encephalitis-induced rotational behaviour. Acta Neuropathol. 87, 259-268. doi: 10.1007/s004010050084

Pandey, J. P., Kothera, R. T., Liu, S., Costa, A. S., Mancuso, R., and Agostini, S. (2019). Immunoglobulin genes and immunity to HSV1 in Alzheimer's disease. J. Alzheimers Dis. 70, 917-924. doi: 10.3233/jad-190265

Perng, G. C., Jones, C., Ciacci-Zanella, J., Stone, M., Henderson, G., Yukht, A., et al. (2000). Virus-induced neuronal apoptosis blocked by the herpes simplex virus latency-associated transcript. Science 287, 1500-1503. doi: 10.1126/science.287. 5457.1500

Petersen, R. C., Doody, R., Kurz, A., Mohs, R. C., Morris, J. C., Rabins, P. V., et al. (2001). Current concepts in mild cognitive impairment. Arch. Neurol. 58, 1985-1992.

Piacentini, R., Li Puma, D. D., Ripoli, C., Marcocci, M. E., De Chiara, G., Garaci, E., et al. (2015). Herpes simplex virus type-1 infection induces synaptic dysfunction in cultured cortical neurons via GSK-3 activation and intraneuronal amyloidbeta protein accumulation. Sci. Rep. 5:15444.

Pisa, D., Alonso, R., Fernandez-Fernandez, A. M., Rabano, A., and Carrasco, L. (2017). Polymicrobial infections in brain tissue from Alzheimer's disease patients. Sci. Rep. 7:5559.

Polk, S., Munoz, A., Sacktor, N. C., Jenkins, F. J., Cohen, B., Miller, E. N., et al. (2002). A case-control study of HIV-1-related dementia and co-infection with HHV-8. Neurology 59, 950-953. doi: 10.1212/wnl.59.6.950

Powell-Doherty, R. D., Abbott, A. R. N., Nelson, L. A., and Bertke, A. S. (2020). Amyloid-beta and p-Tau Anti-Threat response to HSV-1 infection in primary adult murine hippocampal neurons. J. Virol. 94:e1874-19.

Prandovszky, E., Horvath, S., Gellert, L., Kovacs, S. K., Janka, Z., Toldi, J., et al. (2008). Nectin-1 (HveC) is expressed at high levels in neural subtypes that regulate radial migration of cortical and cerebellar neurons of the developing human and murine brain. J. Neurovirol. 14, 164-172. doi: 10.1080/ 13550280801898672

Protto, V., Tramutola, A., Fabiani, M., Marcocci, M. E., Napoletani, G., Iavarone, F., et al. (2020). Multiple herpes simplex virus-1 (HSV-1) reactivations induce protein oxidative damage in mouse brain: novel mechanisms for Alzheimer's disease progression. Microorganisms 8:972. doi: 10.3390/ microorganisms 8070972

Qiu, C., Kivipelto, M., and von Strauss, E. (2009). Epidemiology of Alzheimer's disease: occurrence, determinants, and strategies toward intervention. Dialogues Clin. Neurosci. 11, 111-128. doi: 10.31887/dcns.2009.11.2/cqiu

Rapraeger, A. C., Krufka, A., and Olwin, B. B. (1991). Requirement of heparan sulfate for bFGF-mediated fibroblast growth and myoblast differentiation. Science 252, 1705-1708. doi: 10.1126/science.1646484

Readhead, B., Haure-Mirande, J. V., Funk, C. C., Richards, M. A., Shannon, P., Haroutunian, V., et al. (2018). Multiscale analysis of independent Alzheimer's cohorts finds disruption of molecular, genetic, and clinical networks by human herpesvirus. Neuron 99, 64-82 e67.

Reinert, L. S., Lopusna, K., Winther, H., Sun, C., Thomsen, M. K., Nandakumar, R., et al. (2016). Sensing of HSV-1 by the cGAS-STING pathway in microglia orchestrates antiviral defence in the CNS. Nat. Commun. 7:13348.

Reul, J. M., Pearce, P. T., Funder, J. W., and Krozowski, Z. S. (1989). Type I and type II corticosteroid receptor gene expression in the rat: effect of adrenalectomy and dexamethasone administration. Mol. Endocrinol. 3, 1674-1680. doi: 10.1210/ mend-3-10-1674

Riancho, J., Delgado-Alvarado, M., Sedano, M. J., Polo, J. M., and Berciano, J. (2013). Herpes simplex encephalitis: clinical presentation, neurological sequelae and new prognostic factors. ten years of experience. Neurol. Sci. 34, 1879-1881. doi: 10.1007/s10072-013-1475-9

Ribes, J. A., Steele, A. D., Seabolt, J. P., and Baker, D. J. (2001). Six-year study of the incidence of herpes in genital and nongenital cultures in a central Kentucky medical center patient population. J. Clin. Microbiol. 39, 3321-3325. doi: 10.1128/jcm.39.9.3321-3325.2001

Rodriguez-Callejas, J. D., Fuchs, E., and Perez-Cruz, C. (2020). Increased oxidative stress, hyperphosphorylation of tau, and dystrophic microglia in the 
hippocampus of aged Tupaia belangeri. Glia 68, 1775-1793. doi: 10.1002/glia. 23804

Rotschafer, J. H., Hu, S., Little, M., Erickson, M., Low, W. C., and Cheeran, M. C. (2013). Modulation of neural stem/progenitor cell proliferation during experimental herpes simplex encephalitis is mediated by differential FGF-2 expression in the adult brain. Neurobiol. Dis. 58, 144-155. doi: 10.1016/j.nbd. 2013.05.018

Sait, A., Angeli, C., Doig, A. J., and Day, P. J. R. (2021). Viral involvement in Alzheimer's disease. ACS Chem. Neurosci. 12, 1049-1060.

Santana, S., Recuero, M., Bullido, M. J., Valdivieso, F., and Aldudo, J. (2012). Herpes simplex virus type I induces the accumulation of intracellular $\beta$-amyloid in autophagic compartments and the inhibition of the non-amyloidogenic pathway in human neuroblastoma cells. Neurobiol. Aging 33, 430.e419430.e433.

Satpute-Krishnan, P., DeGiorgis, J. A., and Bearer, E. L. (2003). Fast anterograde transport of herpes simplex virus: role for the amyloid precursor protein of Alzheimer's disease. Aging Cell 2, 305-318. doi: 10.1046/j.1474-9728.2003. 00069.x

Sawiris, G. P., Sydiskis, R. J., and Bashirelahi, N. (1994). Hormonal modulation of herpes simplex virus replication in a mouse neuroblastoma cell line. J. Clin. Lab. Anal. 8, 135-139. doi: 10.1002/jcla.1860080304

Sawtell, N. M., and Thompson, R. L. (2016). De novo herpes simplex virus VP16 expression gates a dynamic programmatic transition and sets the latent/Lytic balance during acute infection in trigeminal ganglia. PLoS Pathog. 12:e1005877. doi: 10.1371/journal.ppat.1005877

Sawtell, N. M., Thompson, R. L., Stanberry, L. R., and Bernstein, D. I. (2001). Early intervention with high-dose acyclovir treatment during primary herpes simplex virus infection reduces latency and subsequent reactivation in the nervous system in vivo. J. Infect. Dis. 184, 964-971. doi: 10.1086/323551

Schnier, C., Janbek, J., Williams, L., Wilkinson, T., Munk Laursen, T., Waldemar, G., et al. (2021). Antiherpetic medication and incident dementia: observational cohort studies in four countries. Eur. J. Neurol. 28, 1840-1848. doi: 10.1111/ ene. 14795

Scott, D. A., Coulter, W. A., Biagioni, P. A., O’Neill, H. O., and Lamey, P. J. (1997). Detection of herpes simplex virus type 1 shedding in the oral cavity by polymerase chain reaction and enzyme-linked immunosorbent assay at the prodromal stage of recrudescent herpes labialis. J. Oral Pathol. Med. 26, 305-309. doi: 10.1111/j.1600-0714.1997.tb00220.x

Shirts, B. H., Prasad, K. M., Pogue-Geile, M. F., Dickerson, F., Yolken, R. H., and Nimgaonkar, V. L. (2008). Antibodies to cytomegalovirus and herpes simplex virus 1 associated with cognitive function in schizophrenia. Schizophr. Res. 106, 268-274. doi: 10.1016/j.schres.2008.07.017

Shukla, D., Liu, J., Blaiklock, P., Shworak, N. W., Bai, X., Esko, J. D., et al. (1999). A novel role for 3-O-sulfated heparan sulfate in herpes simplex virus 1 entry. Cell 99, 13-22. doi: 10.1016/s0092-8674(00)80058-6

Small, S. A., Schobel, S. A., Buxton, R. B., Witter, M. P., and Barnes, C. A. (2011). A pathophysiological framework of hippocampal dysfunction in ageing and disease. Nat. Rev. Neurosci. 12, 585-601. doi: 10.1038/nrn3085

Snow, A. D., Mar, H., Nochlin, D., Kresse, H., and Wight, T. N. (1992). Peripheral distribution of dermatan sulfate proteoglycans (decorin) in amyloid-containing plaques and their presence in neurofibrillary tangles of Alzheimer's disease. J. Histochem. Cytochem. 40, 105-113. doi: 10.1177/40.1.1370306

Snyder, A., Polcicova, K., and Johnson, D. C. (2008). Herpes simplex virus gE/gI and US9 proteins promote transport of both capsids and virion glycoproteins in neuronal axons. J. Virol. 82, 10613-10624. doi: 10.1128/jvi.01241-08

Sodeik, B., Ebersold, M. W., and Helenius, A. (1997). Microtubule-mediated transport of incoming herpes simplex virus 1 capsids to the nucleus. J. Cell Biol. 136, 1007-1021. doi: 10.1083/jcb.136.5.1007

Steel, A. J., and Eslick, G. D. (2015). Herpes viruses increase the risk of Alzheimer's disease: a meta-analysis. J. Alzheimers Dis. 47, 351-364. doi: 10.3233/jad140822

Stephan, B. C., Hunter, S., Harris, D., Llewellyn, D. J., Siervo, M., Matthews, F. E., et al. (2012). The neuropathological profile of mild cognitive impairment (MCI): a systematic review. Mol. Psychiatry 17, 1056-1076. doi: 10.1038/mp. 2011.147

Stowe, R. P., Peek, M. K., Cutchin, M. P., and Goodwin, J. S. (2012). Reactivation of herpes simplex virus type 1 is associated with cytomegalovirus and age. J. Med. Virol. 84, 1797-1802. doi: 10.1002/jmv.23397
Strandberg, T. E., Pitkala, K. H., Linnavuori, K. H., and Tilvis, R. S. (2003). Impact of viral and bacterial burden on cognitive impairment in elderly persons with cardiovascular diseases. Stroke 34, 2126-2131. doi: 10.1161/01.str.0000086754. 32238.da

Streit, W. J., Braak, H., Xue, Q. S., and Bechmann, I. (2009). Dystrophic (senescent) rather than activated microglial cells are associated with tau pathology and likely precede neurodegeneration in Alzheimer's disease. Acta Neuropathol. 118, 475-485. doi: 10.1007/s00401-009-0556-6

Stroop, W. G., McKendall, R. R., Battles, E. J., Schaefer, D. C., and Jones, B. (1990). Spread of herpes simplex virus type 1 in the central nervous system during experimentally reactivated encephalitis. Microb. Pathog. 8, 119-134. doi: 10.1016/0882-4010(90)90076-3

Suenaga, T., Satoh, T., Somboonthum, P., Kawaguchi, Y., Mori, Y., and Arase, H. (2009). Myelin-associated glycoprotein mediates membrane fusion and entry of neurotropic herpesviruses. Proc. Natl. Acad. Sci. U.S.A. 107, 866-871. doi: 10.1073/pnas.0913351107

Suzich, J. B., and Cliffe, A. R. (2018). Strength in diversity: understanding the pathways to herpes simplex virus reactivation. Virology 522, 81-91. doi: 10 . 1016/j.virol.2018.07.011

Takasu, T., Furuta, Y., Sato, K. C., Fukuda, S., Inuyama, Y., and Nagashima, K. (1992). Detection of latent herpes simplex virus DNA and RNA in human geniculate ganglia by the polymerase chain reaction. Acta Otolaryngol. 112, 1004-1011. doi: 10.3109/00016489209137502

Tanaka, T., Matsuda, T., Hayes, L. N., Yang, S., Rodriguez, K., Severance, E. G., et al. (2017). Infection and inflammation in schizophrenia and bipolar disorder. Neurosci. Res. 115, 59-63.

Tarter, K. D., Simanek, A. M., Dowd, J. B., and Aiello, A. E. (2014). Persistent viral pathogens and cognitive impairment across the life course in the third national health and nutrition examination survey. J. Infect. Dis. 209, 837-844. doi: 10.1093/infdis/jit616

Theil, D., Arbusow, V., Derfuss, T., Strupp, M., Pfeiffer, M., Mascolo, A., et al. (2001). Prevalence of HSV-1 LAT in human trigeminal, geniculate, and vestibular ganglia and its implication for cranial nerve syndromes. Brain Pathol. 11, 408-413. doi: 10.1111/j.1750-3639.2001.tb00408.x

Thompson, R. L., Preston, C. M., and Sawtell, N. M. (2009). De novo synthesis of VP16 coordinates the exit from HSV latency in vivo. PLoS Pathog. 5:e1000352. doi: 10.1371/journal.ppat.1000352

Tomlinson, A. H., and Esiri, M. M. (1983). Herpes simplex encephalitis. immunohistological demonstration of spread of virus via olfactory pathways in mice. J. Neurol. Sci. 60, 473-484.

Toscano, E. C. B., Sousa, L., Lima, G. K., Mesquita, L. A., Vilela, M. C., Rodrigues, D. H., et al. (2020). Neuroinflammation is associated with reduced SOCS2 and SOCS3 expression during intracranial HSV-1 infection. Neurosci. Lett. 736:135295. doi: 10.1016/j.neulet.2020.135295

Tsai, M. C., Cheng, W. L., Sheu, J. J., Huang, C. C., Shia, B. C., Kao, L. T., et al. (2017). Increased risk of dementia following herpes zoster ophthalmicus. PLoS One 12:e0188490. doi: 10.1371/journal.pone.0188490

Twomey, J. A., Barker, C. M., Robinson, G., and Howell, D. A. (1979). Olfactory mucosa in herpes simplex encephalitis. J. Neurol. Neurosurg. Psychiatry 42, 983-987. doi: 10.1136/jnnp.42.11.983

Tzeng, N. S., Chung, C. H., Lin, F. H., Chiang, C. P., Yeh, C. B., Huang, S. Y., et al. (2018). Anti-herpetic medications and reduced risk of dementia in patients with herpes simplex virus infections-a nationwide, population-based cohort study in Taiwan. Neurotherapeutics 15, 417-429. doi: 10.1007/s13311-018-0611-x

Umbach, J. L., Kramer, M. F., Jurak, I., Karnowski, H. W., Coen, D. M., and Cullen, B. R. (2008). MicroRNAs expressed by herpes simplex virus 1 during latent infection regulate viral mRNAs. Nature 454, 780-783. doi: 10.1038/ nature 07103

Vanyukov, M. M., Nimgaonkar, V. L., Kirisci, L., Kirillova, G. P., Reynolds, M. D., Prasad, K., et al. (2018). Association of cognitive function and liability to addiction with childhood herpesvirus infections: a prospective cohort study. Dev. Psychopathol. 30, 143-152. doi: 10.1017/s0954579417000529

Verbeek, M. M., Otte-Holler, I., van den Born, J., van den Heuvel, L. P., David, G., Wesseling, P., et al. (1999). Agrin is a major heparan sulfate proteoglycan accumulating in Alzheimer's disease brain. Am. J. Pathol. 155, 2115-2125. doi: 10.1016/s0002-9440(10)65529-0

Vicario-Abejon, C., Johe, K. K., Hazel, T. G., Collazo, D., and McKay, R. D. (1995). Functions of basic fibroblast growth factor and neurotrophins in the 
differentiation of hippocampal neurons. Neuron 15, 105-114. doi: 10.1016/ 0896-6273(95)90068-3

Vigasova, D., Nemergut, M., Liskova, B., and Damborsky, J. (2021). Multipathogen infections and Alzheimer's disease. Microb. Cell Fact. 20:25.

Vilensky, J. A., Hoesen, G. W. V., and Damasio, A. R. (1982). The limbic system and human evolution. J. Hum. Evol. 11, 447-460. doi: 10.1016/s0047-2484(82) 80099-7

Wainberg, M., Luquez, T., Koelle, D. M., Readhead, B., Johnston, C., Darvas, M., et al. (2021). The viral hypothesis: how herpesviruses may contribute to Alzheimer's disease. Mol. Psychiatry 18:55.

Wang, Q. Y., Zhou, C., Johnson, K. E., Colgrove, R. C., Coen, D. M., and Knipe, D. M. (2005). Herpesviral latency-associated transcript gene promotes assembly of heterochromatin on viral lytic-gene promoters in latent infection. Proc. Natl. Acad. Sci. U.S.A. 102, 16055-16059. doi: 10.1073/pnas.0505850102

Wang, Q., Van Heerikhuize, J., Aronica, E., Kawata, M., Seress, L., Joels, M., et al. (2013). Glucocorticoid receptor protein expression in human hippocampus; stability with age. Neurobiol. Aging 34, 1662-1673.

Wang, Q., Yang, L., Alexander, C., and Temple, S. (2012). The niche factor syndecan-1 regulates the maintenance and proliferation of neural progenitor cells during mammalian cortical development. PLoS One 7:e42883. doi: 10. 1371/journal.pone.0042883

Warren-Gash, C., Forbes, H. J., Williamson, E., Breuer, J., Hayward, A. C., Mavrodaris, A., et al. (2019). Human herpesvirus infections and dementia or mild cognitive impairment: a systematic review and meta-analysis. Sci. Rep. 9:4743.

Watson, A. M., Prasad, K. M., Klei, L., Wood, J. A., Yolken, R. H., Gur, R. C., et al. (2013). Persistent infection with neurotropic herpes viruses and cognitive impairment. Psychol. Med. 43, 1023-1031.

Webb, S. J., Eglin, R. P., Reading, M., and Esiri, M. M. (1989). Experimental murine herpes simplex encephalitis: immunohistochemical detection of virus antigens. Neuropathol. Appl. Neurobiol. 15, 165-174. doi: 10.1111/j.1365-2990. 1989.tb01218.x

Whitbeck, J. C., Peng, C., Lou, H., Xu, R., Willis, S. H., Ponce, et al. (1997). Glycoprotein D of herpes simplex virus (HSV) binds directly to HVEM, a member of the tumor necrosis factor receptor superfamily and a mediator of HSV entry. J. Virol. 71, 6083-6093. doi: 10.1128/jvi.71.8.6083-6093.1997

Whitley, R., and Baines, J. (2018). Clinical management of herpes simplex virus infections: past, present, and future. F1000Res 7:F1000.

Whitley, R., Arvin, A., Prober, C., Corey, L., Burchett, S., Plotkin, S., et al. (1991). Predictors of morbidity and mortality in neonates with herpes simplex virus infections. the national institute of allergy and infectious diseases collaborative antiviral study group. N. Engl. J. Med. 324, 450-454. doi: 10.1056/ nejm199102143240704

Whitley, R., Davis, E. A., and Suppapanya, N. (2007). Incidence of neonatal herpes simplex virus infections in a managed-care population. Sex. Transm. Dis. 34, 704-708. doi: 10.1097/01.olq.0000258432.33412.e2

Wozniak, M. A., Frost, A. L., and Itzhaki, R. F. (2009a). Alzheimer's disease-specific tau phosphorylation is induced by herpes simplex virus type 1. J. Alzheimers Dis 16, 341-350. doi: 10.3233/jad-2009-0963

Wozniak, M. A., Frost, A. L., and Itzhaki, R. F. (2013). The helicase-primase inhibitor BAY 57-1293 reduces the Alzheimer's disease-related molecules induced by herpes simplex virus type 1. Antivir. Res. 99, 401-404. doi: 10.1016/ j.antiviral.2013.07.003

Wozniak, M. A., Frost, A. L., Preston, C. M., and Itzhaki, R. F. (2011). Antivirals reduce the formation of key Alzheimer's disease molecules in cell cultures acutely infected with herpes simplex virus type 1. PLoS One 6:e25152. doi: 10.1371/journal.pone.0025152

Wozniak, M. A., Itzhaki, R. F., Shipley, S. J., and Dobson, C. B. (2007). Herpes simplex virus infection causes cellular $\beta$-amyloid accumulation and secretase upregulation. Neurosci. Lett. 429, 95-100. doi: 10.1016/j.neulet.2007.09.077
Wozniak, M. A., Mee, A. P., and Itzhaki, R. F. (2009b). Herpes simplex virus type 1 DNA is located within Alzheimer's disease amyloid plaques. J. Pathol. 217, 131-138. doi: 10.1002/path.2449

Wozniak, M. A., Shipley, S. J., Combrinck, M., Wilcock, G. K., and Itzhaki, R. F. (2005). Productive herpes simplex virus in brain of elderly normal subjects and Alzheimer's disease patients. J. Med. Virol. 75, 300-306. doi: 10. 1002/jmv.20271

Wozniak, M., Bell, T., Denes, A., Falshaw, R., and Itzhaki, R. (2015). Anti-HSV1 activity of brown algal polysaccharides and possible relevance to the treatment of Alzheimer's disease. Int. J. Biol. Macromol. 74, 530-540. doi: 10.1016/j. ijbiomac.2015.01.003

Wu, D., Wang, C., Pang, P., Kong, H., Lin, Z., Wang, H., et al. (2020). The association between herpes simplex virus type 1 infection and Alzheimer's disease. J. Clin. Neurosci. 82, 63-70.

WuDunn, D., and Spear, P. G. (1989). Initial interaction of herpes simplex virus with cells is binding to heparan sulfate. J. Virol. 63, 52-58. doi: 10.1128/jvi.63. 1.52-58.1989

Yan, C., Luo, Z., Li, W., Li, X., Dallmann, R., Kurihara, H., et al. (2020). Disturbed Yin-Yang balance: stress increases the susceptibility to primary and recurrent infections of herpes simplex virus type 1. Acta Pharm. Sin. B 10, 383-398. doi: 10.1016/j.apsb.2019.06.005

Yayon, A., Klagsbrun, M., Esko, J. D., Leder, P., and Ornitz, D. M. (1991). Cell surface, heparin-like molecules are required for binding of basic fibroblast growth factor to its high affinity receptor. Cell 64, 841-848. doi: 10.1016/00928674(91)90512-w

Yolken, R. H., Torrey, E. F., Lieberman, J. A., Yang, S., and Dickerson, F. B. (2011). Serological evidence of exposure to Herpes simplex virus type 1 is associated with cognitive deficits in the CATIE schizophrenia sample. Schizophr. Res. 128, 61-65. doi: 10.1016/j.schres.2011.01.020

Yu, C., Griffiths, L. R., and Haupt, L. M. (2017). Exploiting heparan sulfate proteoglycans in human neurogenesis-controlling lineage specification and fate. Front. Integr. Neurosci. 11:28.

Zhang, G. L., Zhang, X., Wang, X. M., and Li, J. P. (2014). Towards understanding the roles of heparan sulfate proteoglycans in Alzheimer's disease. Biomed. Res. Int. 2014:516028.

Zhao, C., Strobino, K., Moon, Y. P., Cheung, Y. K., Sacco, R. L., Stern, Y., et al. (2020). APOE 4 modifies the relationship between infectious burden and poor cognition. Neurol. Genet. 6:e462. doi: 10 . 1212/nxg.0000000000000462

Zheng, W., Klammer, A. M., Naciri, J. N., Yeung, J., Demers, M., Milosevic, J., et al. (2020). Patterns of herpes simplex virus 1 infection in neural progenitor cells. J. Virol. 94, e00994-20. doi: 10.1128/JVI.00994-20

Conflict of Interest: The authors declare that the research was conducted in the absence of any commercial or financial relationships that could be construed as a potential conflict of interest.

Publisher's Note: All claims expressed in this article are solely those of the authors and do not necessarily represent those of their affiliated organizations, or those of the publisher, the editors and the reviewers. Any product that may be evaluated in this article, or claim that may be made by its manufacturer, is not guaranteed or endorsed by the publisher.

Copyright (c) 2021 Yong, Yong, Teoh, Soga, Parhar, Chew and Lim. This is an openaccess article distributed under the terms of the Creative Commons Attribution License (CC BY). The use, distribution or reproduction in other forums is permitted, provided the original author(s) and the copyright owner(s) are credited and that the original publication in this journal is cited, in accordance with accepted academic practice. No use, distribution or reproduction is permitted which does not comply with these terms. 